Volume 64

\title{
The Separate but Unequal Constitution
}

Adam Lamparello

Charles MacLean

Follow this and additional works at: https://via.library.depaul.edu/law-review

\section{Recommended Citation}

Adam Lamparello \& Charles MacLean, The Separate but Unequal Constitution, 64 DePaul L. Rev. (2014) Available at: https://via.library.depaul.edu/law-review/vol64/iss1/3

This Article is brought to you for free and open access by the College of Law at Digital Commons@DePaul. It has been accepted for inclusion in DePaul Law Review by an authorized editor of Digital Commons@DePaul. For more information, please contact digitalservices@depaul.edu. 


\title{
THE SEPARATE BUT UNEQUAL CONSTITUTION
}

\author{
Adam Lamparello* and Charles E. MacLean**
}

TABle of Contents

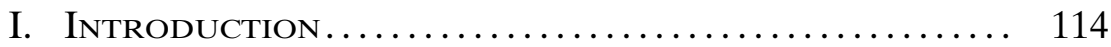

II. Liberty, Equality, and Democratic

GovernancE.............................. 120

A. Equality: Procedural and Substantive ............ 120

1. Procedural Equality....................... 120

2. Substantive Equality ...................... 121

B. Liberty: Classical Versus Contemporary

Liberalism ................................ 122

1. Classical Liberalism....................... 123

2. Contemporary Liberalism ................. 124

C. Pragmatic Democracy and the Countermajoritarian

Problem ................................. 126

1. Democracy as a Guarantor of Equality ........ 127

2. The Courts or the People as Guardians of

Liberty and Equality?................... 127

3. Judicial Review, Individual Rights, and a Participatory Democracy.................... 129

4. The Supreme Court's Liberty Jurisprudence Leads to Procedural and Stubstantive Inequality ............................ 133

III. Today's Separate but Unequal Constitutions .... 137

A. The Goldman Sachs Constitution .............. 138

1. The Decision........................... 138

2. The Impact on Democracy................ 140

B. The Gridlocked Constitution .................. 142

1. The Decision........................... 143

2. The Impact on Democracy................ 144

C. The Third Political Branch Constitution............ 145

1. The Decisions ............................ 145

2. The Impact on Democracy................ 147

* B.A., University of Southern California, J.D., Ohio State University College of Law, LL.M., New York University School of Law.

** B.A., and M.B.A., University of Minnesota, J.D., William Mitchell College of Law. 
D. The Power-Hungry Constitution ............... 148

1. The Decisions ................................... 149

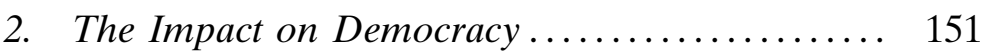

E. The Anemic Constitution .................... 152

1. The Decisions ......................... 153

2. The Impact on Democracy................ 156

F. The Upside-Down Constitution ................. 157

1. The Devolving Definition of Decency ......... 157

2. The Impact on Democracy................. 161

3. Death Is Not Really Different in Democracy.... 162

G. The Laissez-Faire Constitution ................ 163

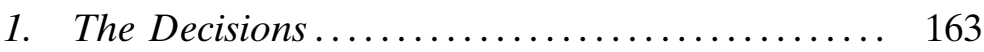

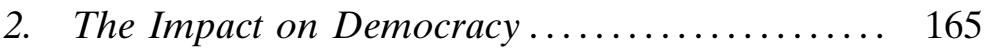

H. The Live Free or Die Constitution .............. 167

1. The Decision.......................... 167

2. The Impact on Democracy................. 169

I. The "Stare Indecisis" Constitution................ 170

1. The Decisions ........................... 171

2. The Impact on Democracy................ 174

J. The Larcenous Constitution ................... 175

1. The Decision.......................... 175

2. The Impact on Democracy............... 177

IV. Reasonably Construing the Constitution's Text, Protecting Individual Rights, AND

Preserving Democracy ....................... 178

A. Pragmatism and Individual Rights: United States v.

Windsor.............................. 178

B. Intrastate Application of the Eighth Amendment .... 180

V. Conclusion ............................... 182

\section{INTRODUCTION}

There is only one Constitution, ${ }^{1}$ and it is written. The Constitution's words are authoritative, but they are not conclusive. And

1. See Richard A. Posner, A Lawyer's Dozen, New Republic, Nov. 8, 2012, at 36. In his review of Yale Law Professor Akhil Amar's America's Unwritten Constitution, Seventh Circuit Judge Richard Posner claims that Amar advocates for eleven unwritten constitutions: an "implicit" constitution, a "lived" constitution, a "Warrented" constitution (in reference to Earl Warren), a "doctrinal" constitution, a "symbolic" constitution, a "feminist" constitution, a "Georgian" constitution (in reference to George Washington), an "institutional" constitution, a "partisan" constitution (in reference to political parties, which are not mentioned in the written Constitution), a "conscientious" constitution (which, for example, permits judges and jurors to ignore valid law), and an "unfinished" constitution that "Amar is busy finishing." Id. 
neither originalism, ${ }^{2}$ nor the "dynamic approach,"3 can solve the mysteries presented by the Constitution's generalized language. What can be said, however, is that the Constitution contains three written and unwritten mandates that unite its structural and individual rights sections: equality, liberty, and democratic governance. ${ }^{4}$ This article argues that equality is the prerequisite to an enduring form of liberty and a truer democracy. It defines equality as increasing citizen participation in the legislative process through a political system in which votes actually matter and elected officials are more accountable to those they serve. Without equality, neither liberty nor democracy, in the forms envisioned by the Constitution, is possible.

The United States Supreme Court has failed to bring us closer to this vision. Instead, the Court has created a separate but unequal Constitution that is "living"5 for all of the wrong reasons and "evolving" in undemocratic ways. This is not an indictment or attack on the Court, but it is the consequence of three fundamental errors that have plagued its jurisprudence: the Court's predilection to focus its opinions not on constitutional principles, but on outcomes, uniformity, and inconsistency. And it is also about power-the Court's own power vis-à-vis, and at the expense of, the power exercised by the people and the coordinate branches.

To be sure, there is nothing inherently wrong with a focus on outcomes. The Justices are pragmatists, ${ }^{7}$ not robots. They do not apply legal rules in a vacuum, and often make "choices that entail the exercise of legislative-like judicial discretion." 8 They understand that law is not separate from politics, just as opinions are not without consequences. ${ }^{9}$ Thus, pragmatism should not be viewed as a tool for judicial activism, but as the desire to be "reasonable in light of the warring interests in the cases." 10 Likewise, legislators and commentators

2. Diane P. Wood, Our 18th Century Constitution in the 21st Century World, 80 N.Y.U. L. REV. 1079, 1080 (2005).

3. $I d$.

4. See James E. Fleming, Securing Deliberative Autonomy, 48 Stan. L. Rev. 1, 21-22 (1995).

5. See James E. Fleming, Living Originalism and Living Constitutionalism as Moral Readings of the American Constitution, 92 B.U. L. Rev. 1171, 1175 (2012).

6. Bertrall L. Ross II, Against Constitutional Mainstreaming, 78 U. ChI. L. Rev. 1203, 1208 (2011).

7. Edward Whelan, How Judge Posner Thinks Judges Should Think: An Unpersuasive Case for Pragmatism, NAT'L Rev. Online (Apr. 17, 2008, 4:00 AM), http://www.nationalreview.com/ articles/224135/how-judge-posner-thinks-judges-should-think/edward-whelan\#.

8. Richard Posner, How Judges Think 203 (2008).

9. Whelan, supra note 7.

10. Posner, supra note 8 , at 249. 
should also hesitate before seeking the abolition of pragmatism, ${ }^{11}$ which would "make judges even less candid than they are" 12 and "inadvertently give greater play to judges' personal and political preconceptions in cases involving discretion." 13 Scholars should rethink the value of endlessly debating interpretive theories, arguing that the Constitution has numerous unwritten constitutions, ${ }^{14}$ or claiming to have identified the unspoken purposes underlying the Constitution's text. ${ }^{15}$ The focus should be on finding the right kind of pragmatism.

The Supreme Court's current pragmatism is understandable, but not the right approach. It is driven, in part, by an institutional reality: the Court's decision is the final word. Its interpretation of a law or statute becomes the policy that will govern individuals, groups, and institutions for the foreseeable future-and perhaps forever. After all, no other branch can invalidate a Court opinion as unconstitutional. The Court alone has the final say. As a result, while legal formalisms and textually-derived penumbras ${ }^{16}$ may give the Court's decisions the "appearance of judicial rigor," 17 they are more aptly described as pragmatic attempts to find the right answers for everyone. As discussed in Part II, those answers have resulted in inconsistency, inequality, and misguided uniformity.

Under its Eighth Amendment jurisprudence, for example, the Court has prohibited every state from executing child rapists. ${ }^{18}$ Its Sixth Amendment jurisprudence, however, has allowed every state to effectively deprive indigent defendants of the right to counsel, which has led to grave injustices, including the execution of innocent people. ${ }^{19}$ Furthermore, in the context of the Fourteenth Amendment, the Court has issued highly questionable and sweeping rulings ${ }^{20}$ that have removed social policy questions from democratic discourse. But the Court's First Amendment jurisprudence has allowed corporations and lobbyists to become contemporary de facto "citizens," and has severely compromised the political process. And if, as Yale Law School

\footnotetext{
11. Whelan, supra note 7.

12. Posner, supra note 8 , at 251.

13. Whelan, supra note 7.

14. See, e.g., Stephen E. Sachs, The "Unwritten Constitution" and Unwritten Law, 2013 U. ILL. L. REv. 1797, 1802.

15. See, e.g., Lawrence B. Solum, Originalism and the Unwritten Constitution, 2013 U. ILL. L. REv. 1935, 1954.

16. See, e.g., Griswold v. Connecticut, 381 U.S. 479, 483 (1965).

17. Whelan, supra note 7.

18. Kennedy v. Louisiana, 554 U.S. 407, 446 (2008).

19. See Strickland v. Washington, 466 U.S. 668,689 (1984).

20. See, e.g., Roe v. Wade, 410 U.S. 113 (1973).
} 
Professor Akhil Amar argues, "clause-bound interpretivism" 21 or "intratextualism" 22 should be rejected in favor of an "organic-unity holism," 23 then it begs the question of why the Court's jurisprudence is anything but holistic. ${ }^{24}$ One answer might be that the "what works best" approach ${ }^{25}$ for each Justice is entirely subjective and depends on the interpretive lens through which that Justice views the Constitution. Often, it depends not only on what the Constitution means, but what each Justice wants it to mean. Thus, the Court's opinions are often more an exercise in each Justice's will than an exercise in principled and constitutional jurisprudence.

That, however, should not be the focus of debate. Since pragmatism does not "grind[ ] out certifiably correct answers to legal questions," 26 and "a reasonable decision is not necessarily a 'right' one," 27 the real question is whether the Court's pragmatism has in fact led to a higher degree of citizen participation in the political and democratic process. As discussed below, the answer in the individual rights context is no. The Court's decisions, for example, have thwarted the coordinate branches' attempts to repair the political process through campaign finance legislation, and have prevented states from addressing uniquely local problems. ${ }^{28}$ Tellingly, in many cases, the Court could only get to these results through manipulating or ignoring the Constitution's text, ${ }^{29}$ or by creating dubious legal doctrines-such as substantive due process ${ }^{30}$ - to give its decisions the "appearance of intellectual rigor." 31 Of course, substantive due process, which can be

21. James E. Fleming, Constructing the Substantive Constitution, 72 Tex. L. Rev. 211, 222 (1993).

22. Adrian Vermeule \& Ernest A. Young, Hercules, Herbert, and Amar: The Trouble with Intratextualism, 113 HARV. L. REv. 730, 756 (2000).

23. Solum, supra note 15, at 1963.

24. See Akhil Reed Amar, Heller, HLR, and Holistic Legal Reasoning, 122 HARv. L. Rev. 145,168 (2008) ("Intratextual analysis is a centuries-old and often elegant form of holistic legal reasoning, but one that must be used with caution and close attention to context.").

25. Christos Papapetrou, Payton, Practical Wisdom, and the Pragmatist Judge: Is Payton's Goal To Prevent Unreasonable Entries or To Effectuate Home Arrests?, 34 FordHam Urb. L.J. 1517, 1527-28 (2007).

26. Posner, supra note 8, at 249.

27. $I d$.

28. See, e.g., Citizens United v. FEC, 558 U.S. 310 (2010).

29. Martin H. Redish \& Matthew B. Arnould, Judicial Review, Constitutional Interpretation, and the Democratic Dilemma: Proposing a "Controlled Activism" Alternative, 64 Fla. L. Rev. 1485, 1491 (2012).

30. See Kermit Roosevelt III, Forget the Fundamental: Fixing Substantive Due Process, 8 U. PA. J. Const. L. 983, 984 (2006).

31. Posner, supra note 8, at 176. 
traced to the Court's early jurisprudence, ${ }^{32}$ would not be problematic if its intent were to increase equality in the democratic and political process. But substantive due process has been used to circumvent the Constitution's textual limits on judicial review. The result is a separate but unequal Constitution. It works for the wealthy. It rewards the powerful. But it ignores the poor, the disenfranchised, and the disempowered.

This Article argues for a new type of pragmatism and recognizes that categorical approaches, such as curtailing judicial review, ${ }^{33}$ letting the states decide, ${ }^{34}$ or reforming the nomination process, ${ }^{35}$ are not realistic. It begins by recognizing that, for better or worse, the Court has become the third political branch. ${ }^{36}$ For example, advocacy groups have increasingly looked to the Court, not the legislature, to address fundamental questions involving government power and individual rights. ${ }^{37}$ Additionally, the Constitution's text is not determinative, and its words are destined to evolve in light of contemporary norms. ${ }^{38}$ Given these facts, and coupled with its role as the final arbiter of these disputes, the Court's approach has predictably transcended legal formalism. It has embraced, either out of need or desire, a pragmatic philosophy. ${ }^{39}$

The right kind of pragmatism should focus less on defining liberty, equality, and democracy, and more on how they can be harmonized to achieve equal access to the political and legislative processes so that citizens can, within constitutional constraints, define and live under their definitions of liberty. Thus, the Court's jurisprudence should strive to (1) enhance individual participation in the political process;

32. Roosevelt, supra note 30, at 984-85; see also Stephen M. Feldman, Unenumerated Rights in Different Democratic Regimes, 9 U. P. J. Const. L. 47, 47 (2006).

33. See Erwin Chemerinsky, In Defense of Judicial Review: The Perils of Popular Constitutionalism, 2004 U. Ill. L. REv. 673, 677.

34. See Robert Justin Lipkin, Which Constitution? Who Decides?: The Problem of Judicial Supremacy and the Interbranch Solution, 28 Cardozo L. Rev. 1055, 1107 (2006).

35. See Elizabeth Anderson, The Problem of Politics and Appointments to the Federal Bench: Looking to England for Guidance in Creating a Less Politicized Process, 47 New Eng. L. Rev. 653, 657-60 (2013).

36. See Frank B. Cross, Law as Courtesy?, 47 Tulsa L. Rev. 219, 222-223 (2011) (reviewing Keith J. Bybee, All Judges Are Political Except When They Are Not: Acceptable Hypocrisies AND the Rule of LAW (2010)).

37. See, e.g., Scott L. Cummings \& Douglas NeJaime, Lawyering for Marriage Equality, 57 UCLA L. REv. 1235, 1238-39 (2010) (discussing the evolution of marriage equality through the courts).

38. Lawrence Rosenthal, Originalism in Practice, 87 InD. L.J. 1183, 1189-90 (2012).

39. See Steven G. Calabresi, A Critical Introduction to the Originalism Debate, 31 Harv. J.L. \& Pub. Pol'y 875, 886-87 (2008). “Modern-day advocates of pragmatism as the correct theory of judicial decision-making think judges should give a lot of weight to the consequences their decisions produce." Id. at 887. 
(2) facilitate the efficient administration of government; (3) give states more latitude to address uniquely local problems; and (4) allow states to arrive at different reasonable conclusions on social rights issues. If legislation cannot be said to violate the Constitution's text, or the Court's precedent, then the Court should allow it to be resolved through the democratic process. In other words, if the Constitution is "unfinished," 40 as Professor Amar claims, then in most cases the people, not the courts, should fill in the blanks.

Part II defines liberty, equality, and democracy. It also discusses the Court's inconsistent approach to individual rights jurisprudence, which has weakened the political and legislative processes.

Part III sets forth a new type of pragmatism by introducing an intrastate conception of the Eighth Amendment that would confine the Court's "evolving standards of decency" 41 analysis to within, rather than among, the states. It is based on the belief that liberty in its truest sense requires citizens to have equal access and influence in the political and legislative processes, and requires courts to analyze state laws in an individualized, rather than collective, manner. In other words, judicial pragmatism should facilitate equal participation, not outcomes. ${ }^{42}$

Part III also addresses the question of when the Court should enforce substantive constitutional values regardless of citizen or legislative choices, and discusses instances when the Court has undermined citizen equality in governance. First, the Court should invalidate duly enacted laws that violate a textual provision of the Constitution. Second, it should address arbitrariness, requiring the invalidation of laws motivated by, among other things, moral views or bias toward individuals or groups. Third, it should find generally-applicable laws facially invalid if they impose an arbitrary burden, and should find laws unconstitutional as applied if they burden an individual's or group's exercise of a fundamental right. Fourth, the Court should focus on protecting minority rights by examining the processes by which a law is adopted, including the degree to which participation is not fully realized. Ultimately, equality is the prerequisite to the type of liberty and democracy that creates rights from citizen engagement-not judicial imposition.

\footnotetext{
40. Posner, supra note 1 , at 40.

41. Trop v. Dulles, 356 U.S. 86, 101 (1958) (plurality opinion).

42. Of course, laws that invidiously discriminate or otherwise subject individuals or groups to discrimination should be invalidated because they violate a specific textual provision. See infra notes 494-496 and accompanying text.
} 


\section{Liberty, Equality, and Democratic Governance}

Liberty, equality, and democratic governance are the foundations of the Constitution's written and unwritten mandates. As United States Supreme Court Justice Stephen Breyer explains, "[T]he Constitution provides a framework for the creation of democratically determined solutions, which protect each individual's basic liberties and assure that individual equal respect by government ...."43 This Article defines equality in both substantive and procedural terms, views liberty through a classical lens, and offers a pragmatic solution to reconcile judicial review with democratic self-governance.

\section{A. Equality: Procedural and Substantive}

Equality "is . . . an elusive concept," 44 particularly because "courts, in exercising their interpretive legal functions, have to provide all persons the equal protection of the laws." 45 The Court's jurisprudence, however, suggests that equality has procedural and substantive aspects, and that they share an interdependent relationship.

\section{Procedural Equality}

Procedural equality is about due process and fairness. In Matthews v. Eldridge, ${ }^{46}$ the Court set forth three factors that are ordinarily required before an individual may be deprived of a constitutionally protected liberty or property interest. The Court held that procedural due process "imposes constraints on governmental decisions which deprive individuals of 'liberty' or 'property' interests within the meaning of the Due Process Clause of the Fifth or Fourteenth Amendment." 47

To begin with, "some form of hearing is required before an individual is finally deprived of a property interest." 48 Indeed, the "right to be heard before being condemned to suffer grievous loss of any kind, even though it may not involve the stigma and hardships of a criminal conviction, is a principle basic to our society." 49 In some cases, this may require "an evidentiary hearing prior to the deprivation." $50 \mathrm{~A}$

43. Stephen Breyer, Our Democratic Constitution, 77 N.Y.U. L. Rev. 245, 271-72 (2002).

44. Berta Esperanza Hernández-Truyol, Virtual Equality as Constitutional Reality: An Introduction, 11 St. John's J. Legal Comment. 1, 1 (1995).

45. Id.

46. 424 U.S. 319, 335 (1976).

47. Id. at 332 .

48. Id. at 333 .

49. Id. (quoting Joint Anti-Fascist Refugee Comm. v. McGrath, 341 U.S. 123, 168 (1951)

(Frankfurter, J., concurring)) (internal quotation marks omitted).

50. Id. at 333 . 
second consideration is the "fairness and reliability of the existing pretermination procedures, and the probable value, if any, of additional procedural safeguards." 51 The final factor considered is "the administrative burden and other societal costs that would be associated with requiring, as a matter of constitutional right, an evidentiary hearing." 52 Ultimately, the fairness of the procedures must be analyzed in light of the "degree of potential deprivation that may be created by a particular decision." 53

Certainly, procedural fairness is vital to ensuring that constitutional rights are protected against arbitrary deprivation. Fair procedures, however, are not sufficient by themselves. The government may not, for example, claim that an otherwise arbitrary law is valid simply because it comports with procedural due process. ${ }^{54}$ As discussed below, equality has substantive aspects, enshrined in the Bill of Rights, which include the right to be free from discrimination and universally applicable but arbitrary laws that uniquely burden the exercise of fundamental liberties. No procedures, no matter how fair, can justify the deprivation of these liberties.

\section{Substantive Equality}

Substantive equality can be neutral, by treating "similarly-situated people similarly." 55 It also authorizes special treatment for certain individuals or groups, or operates to recognize and accommodate differences. ${ }^{56}$ Neutral equality is based on the concept of "treating similarly-situated people similarly" 57 even though "such a formulation does not always yield neutral results." 58 Other definitions are predicated on dominance, and hedonic and pragmatic considerations. ${ }^{59}$ Indeed, the "multiplicity of strands, approaches and definitions, creates more than the appearance" 60 of disagreement, and definitions of

\footnotetext{
51. Id. at 343.

52. Matthews, 424 U.S. at 347.

53. Id. at 341. (1954).

56. Hernández-Truyol, supra note 44 , at 2-3.

57. Id. at 2; see also Brown, 347 U.S. at 495.

58. Hernández-Truyol, supra note 44 , at 2.

59. Id.

60. Id.
}

54. See, e.g., Collins v. Harker Heights, 503 U.S. 115, 125 (1992) (The Due Process Clause "protects individual liberty against 'certain government actions regardless of the fairness of the procedures used to implement them.'” (quoting Daniels v. Williams, 474 U.S. 327, 331 (1986))) .

55. Hernández-Truvol, supra note 44, at 2; see also Brown v. Bd. of Educ., 347 U.S. 400, 495 
equality are "predicated upon ... factors that may be inimical to the very notion of equality, e.g., cultural bias and prejudice."61

Certainly, substantive equality requires, among other things, that individuals be protected from discrimination and arbitrary government conduct that uniquely burdens the exercise of basic liberties. There can be no doubt that substantive equality is enshrined in the Constitution's text and is a prerequisite to a more fully realized liberty.

But the Court has paid insufficient attention to procedural equality and the ways in which it can enhance substantive forms of liberty and facilitate a more participatory democracy. In addition to basic due process protections, procedural equality should also focus on increasing access to the political and democratic spheres. Due process should not simply focus on guarding against arbitrary deprivation by the state, but also on making sure that citizens, who must obey all duly enacted laws, have a meaningful voice in their creation. Not only does this give equality a more substantive meaning, but it also provides liberty with an important procedural safeguard. Specifically, it allows citizens to participate in defining and identifying the rights to which they will be subject. As explained below, this approach supports a classical, not contemporary, understanding of liberty.

\section{B. Liberty: Classical Versus Contemporary Liberalism}

As Justice Breyer explains, "The United States is a nation built on principles of human liberty-a liberty that embraces concepts of democracy."62 Broadly speaking, the "liberty of the ancients" 63 consisted of "active and constant participation in collective power."64 It entrusted to "all the citizens, without exception, the care and assessment of their most sacred interests." 65 A participatory form of liberty "ennobles their thoughts, and establishes among them a kind of intellectual equality which forms the glory and power of a people."66

Classical and contemporary liberalism are similar in some respects. Both theories embrace "the concept that people have certain personal liberties that are intrinsic to respect for them as persons and that are therefore legally and morally inalienable, either by their fellow[ ]citi-

61. Id.

62. Breyer, supra note 43, at 245.

63. Benjamin Constant, The Liberty of the Ancients Compared with That of the Moderns (1816), in Political Writings 309, 309-28 (Biancamaria Fontana trans. \& ed., 1988).

64. Id. at 316.

65. Id. at 327.

66. Id. 
zens or by the State." 67 They also maintain that "a frontier must be drawn between the area of private life and that of public authority," 68 thus creating "a zone of privacy, or area of personal moral liberty secured against governmental intrusion." 69

Importantly, however, classical and contemporary liberalism part ways on the manner in which rights should be created and have different visions of democracy. While both share a view of negative liberty as "the right of individuals to make personal moral decisions free from governmental interference," 70 they diverge in their definition of positive liberty and the creation of rights.

\section{Classical Liberalism}

Classical liberalism asserts that it is "the equal right of each [person] to exercise those individual liberties the people have collectively guaranteed to all by laws enacted on a free and equal basis, including both personal and political liberties." 71 This requires the State "to ensure that personal liberties enumerated in the Constitution or traditionally held to be inalienable are not infringed by the State on any state or federal level." 72

Furthermore, classical liberalism defines positive liberty as the right of the people to design and create their own government based on "such principles as, in their opinion, shall most conduce to their own happiness."73 It grants the people the right "to maintain for themselves, as free and equal citizens, a social compact of ordered liberties grounded in the Constitution and the moral law."74 Thus, positive liberty manifests itself through voting and the legislative acts of the people's representatives, as well as "the interpretive acts of the judiciary." 75 The people, however, retain "the right to refine and redefine those liberties within the constraints they themselves have set out in their Constitution and their laws."76

67. Evelyn Keyes, The Just Society and the Liberal State: Classical and Contemporary Liberalism and the Problem of Consent, 9 Geo. J.L. \& Pub. Pol'y 1, 55 (2011).

68. Isaiah Berlin, Two Concepts of Liberty, in The Proper Study of Mankind 191, 196 (Henry Hardy \& Roger Hausheer eds., 2000).

69. Keyes, supra note 67, at 56 (emphasis omitted).

70. $I d$. at 55 ("[P]eople have private lives in which they are free to make their own moral decisions without the imposition upon them of society's moral point of view.").

71. Id. at 56.

72. Id.

73. Id. (quoting Marbury v. Madison, 5 U.S. (1 Cranch) 137, 176 (1803)).

74. Id.

75. Keyes, supra note 67 , at 56.

76. Id. 


\section{Contemporary Liberalism}

Contemporary liberalism defines positive liberty in a more antidemocratic and less egalitarian sense. ${ }^{77}$ Individuals have an "inalienable equal basic liberty of personal self-determination ... to direct their personal lives in accordance with the 'best' constructions of the rational requirements of liberty and equality ... which the State is independently empowered to identify and enforce."78 While contemporary liberalism emphasizes individual liberty, its purpose is to guard against "the excesses of democratic majorities and those acting in their name." 79 Most notable is the contemporary liberal view of equality:

The contemporary liberal conception of the State as the guarantor of equal basic positive liberties it independently identifies as rationally implied by the core moral concepts of liberty and equality is entirely alien to classical liberalism grounded in a theory of consensual justice. For, in incorporating the concept of the rational and impartial State as independent moral arbiter and guarantor of equal liberty for all, contemporary liberalism necessarily denies the original moral and political right of a free people to participate equally in identifying and defining their own individual basic personal liberties collectively and to constitute their government and adapt their laws as they rationally deem fair and best for all. ${ }^{80}$

Contemporary liberalism also gives states the power "to decree, independently of the will of the people, where equal personal liberty begins and ends under the objectively true principles of justice as fairness." 81 Thus, it "recognizes no constraints, other than the constraints of reason and moral truth, upon the authority of the State to discover the 'truly democratic' requirements of the concepts of equality and liberty." 82

Furthermore, contemporary liberalism is viewed as freeing oneself "from spiritual slavery to one's lower actual self and identifying oneself with one's 'real,' or 'ideal,' or 'autonomous' self, or with [one's] self 'at its best." "83 The real or autonomous self "is then ... associated with the moral, or ideal, rational State, which exerts moral authority over the lower, empirical self." 84 The only principles "recognized as

\footnotetext{
77. $I d$.

78. Id.

79. Breyer, supra note 43 , at 246.

80. Keyes, supra note 67 , at 58.

81. Id. at 57.

82. Id.

83. Id. at 56 (quoting Berlin, supra note 68 , at 204) (alteration in original) (internal quotation marks omitted).

84. Id. at 56-57.
} 
binding upon the sovereign general assembly or independent judiciary are the objectively true principles of justice as fairness." 85

Contemporary liberal theorists therefore believe that it is the "duty of the just State" to assure that privacy and other rights are not "infringed by ... a any citizens or body of citizens, such as a state legislature or a "moral majority." 86 Significantly, contemporary liberalism believes it is the "traditional role of the judiciary to protect them against just that." 87

Ultimately, classical and contemporary liberalism present two competing views regarding "whether it is the role of the State, acting independently through a sovereign assembly or judiciary, or the role of the people, acting through freely and equally elected legislatures and traditional courts, to define the limits of the law." 88

The Court's majority today endorses the contemporary approach. As one commentator explains, "[T]he American courts over the last fifty years have 'discovered' to be implied by the Constitution a number of basic personal positive liberties, or substantive due process rights, neither enumerated in the Constitution nor traditionally recognized by the people, but rationally implied by the concept of equal liberty as developed in contemporary liberal theory." 89 These include, for example, "marital privacy rights, reproductive rights, and abortion rights." 90

The problem is that, while these decisions have arguably resulted in favorable outcomes for various individuals and groups, the path the Court took to get there is paved with fictional legal doctrines that have weakened citizen participation in democracy. In fact, "the concept of implied constitutional substantive due process rights identifiable and enforceable by the judiciary, more than any other, has undermined the ability of contemporary liberalism to secure the consent of the people and thus to ensure its own legitimacy as a governing ideal." 91

\footnotetext{
85. Id. at 57.

86. Keyes, supra note 67, at 56; see also John Stuart Mill, UtilitARIAnism (1859), reprinted in Utilitarianism, On Liberty, Essay on Benthem 126, 129-30 (Mary Warnock ed., 1962).

87. Keyes, supra note 67 , at 59 .

88. Id. at 61 .

89. Id. at 57.

90. Id. at 57-58 (footnotes omitted).

91. Id. at 58.
} 


\section{Pragmatic Democracy and the Countermajoritarian Problem}

"Democracy is difficult to define, not only because it is vague . . . but more importantly, because what one person would regard as a paradigm case another would deny was a democracy at all."92 The common understanding of the word democracy is "government by the people," 93 but this definition is riddled with ambiguities and uncertainties. Professor Spencer Overton states as follows:

In a politically diverse society, no single, universally accepted understanding of democracy exists. Some individuals harbor democratic ideals that focus on broad participation, and look at politics as an inclusive, deliberative process in which actors are largely motivated by the public good. Others view democracy as a competitive, self-serving system in which private interests attempt to use government action to maximize their private gain and government officials make decisions in an attempt to maintain power. Conceptions of democracy often purport to answer certain questions about democracy: What is the relationship between citizens and representatives, majorities and minorities, and public and private interests? Who should be included in the process, and what efforts should be made to include them? Who is competent and trustworthy to make certain decisions? ${ }^{94}$

One view defines democracy "as 'political, social and economic equality,' while another refers to 'a state of society characterized by tolerance toward minorities, freedom of expression, and respect for the essential dignity and worth of the human individual with equal opportunity for each to develop freely his fullest capacity in a cooperative community." "95 Furthermore, "[c]ontextual assumptions about how politics really works or should work not only influence substantive determinations about democracy, such as whether a particular apportionment plan or campaign finance restriction promotes or diminishes effective participation in representative government, but they also affect decisions regarding the appropriate jurisdictional roles of political actors." 96 This leads to various formulations of democracy that are "abundant with meaning and emotive power, and at the same time[,] verging on meaninglessness."97 A common theme, however, focuses on equal access to the democratic process.

92. Allan Ides, The American Democracy and Judicial Review, 33 Ariz. L. Rev. 1, 2 (1991) (quoting The Encyclopedia of Philosophy 338 (1967)) (internal quotation marks omitted).

93. Id. (quoting Webster's Third New World Dictionary 600 (1981)).

94. Spencer Overton, Rules, Standards, and Bush v. Gore: Form and the Law of Democracy, 37 Harv. C.R.-C.L. L. Rev. 65, 84 (2002) (footnotes omitted).

95. Ides, supra note 92, at 2 (quoting Webster's Third New World Dictionary 600 (1981)).

96. Overton, supra note 94, at 85.

97. Ides, supra note 92 , at 2. 


\section{Democracy as a Guarantor of Equality}

"The classic example of participatory democracy ostensibly occurred with the rise of the ancient city-states of Greece, particularly Athens."98 Jean-Jacques Rousseau's vision of democracy was also based upon "full participation by individuals in the process of government." 99

Of course, democracy "is more than a method for enacting laws,"100 but instead "contributes to personal and communal realization" 101 on issues related to liberty and self-governance.

Participation in the process of government uplifts the participants in their knowledge and sensitivity to the needs of others, enhances their sense of mature responsibility, and fully integrates each individual into the community. The requirements of democratic cooperation force the individual to take into account "wider matters than his own immediate private interests."102

Indeed, "an idealized version of the self-contained city-state remains the apotheosis of a participatory democracy." 103

\section{The Courts or the People as Guardians of Liberty and Equality?}

A substantial part of the current debate among constitutional scholars, quite frankly, is whether democracy is a good thing, or whether courts should be the primary protector, expander, and identifier of individual rights. Dean and Professor Erwin Chemerinsky, for example, believes that " $[\mathrm{t}]$ he Constitution purposely is an antimajoritarian document reflecting a distrust of government conducted entirely by majority rule." 104 Along with contemporary liberal theorists, Chemerinsky argues that the Constitution itself is antidemocratic, and reflects the concern that "pure democracy is . . an invitation to tyranny." 105 Accordingly, democracy not only sets forth limits on governmental power, but "protects substantive values from majoritarian pressures."106 Moreover, Chemerinsky views judicial review as "enhanc[ing] democracy by safeguarding these values." 107

\footnotetext{
98. Id. at 4.

99. Id.

100. $I d$.

101. $I d$.

102. Id. (quoting Carole Pateman, Participation and Democratic Theory 25 (1970)).

103. Ides, supra note 92 , at 5 .

104. Erwin Chemerinsky, Interpreting the Constitution 2 (1987).

105. Ides, supra note 92 , at 20.

106. Chemerinsky, supra note 104, at 2.

107. $I d$.
} 
As such, democracy must be contained within a structure of "government designed to limit the perceived dangers of broad-based citizen participation." 108 Chemerinsky also asserts that majority rule must "operate within a structural framework that promotes tolerance for minorities, freedom of expression and respect for the worth and dignity of the individual."109 To realize this vision,

our society should be governed by a constitution, that . . . evolve[s] over time through means other than amendment and [should recognize] that the judiciary is the ideal governmental body to implement that evolution. The reason given at every step of the analysis derives in some manner from a fear of democratic tyranny and a faith in centralized judicial authority. ${ }^{110}$

In other words, courts should not focus primarily on facilitating democratic governance, but instead on protecting the unidentified "substantive values and procedures that society is unwilling to sacrifice to majoritarian preferences." 111

Furthermore, since the Constitution is "sufficiently abstract,"112 it "must be free to adapt to current circumstances" 113 if it is to protect these values and promote social unification. Judicial review is the "structural device designed to undermine those aspects of majority rule seen as inimical to transcendent 'democratic' values."114 Under this view, "once one concludes that an evolving constitution is a good thing, the legitimacy of judicial review is easily established" 115 because it can "best enforce the Constitution against the desires of political majorities." 116 This approach, however, sanctions a system where "[t]he antimajoritarian values of the Constitution are best protected by a nonmajoritarian institution." 117 It also "ignores completely the participatory theory of democracy and any potential values inherent in a system of government more closely aligned with that theory." 118

In effect, Chemerinsky's philosophy endorses a "discourse of unity," 119 which maintains that robust judicial review is compatible

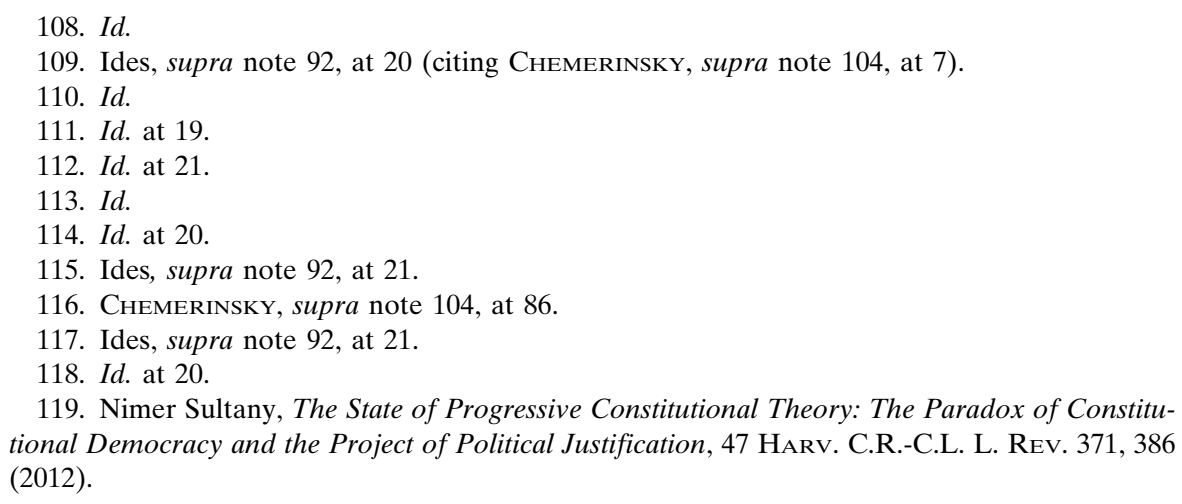


with democracy. Supporters of this theory believe that democratic governance and judicial review can have a harmonious, even complementary, relationship. ${ }^{120}$ The theory encompasses those who believe that there is no "tension between constitutionalism and democracy"121 and those who acknowledge tension but believe it can be "reconciled through changes in the role or form of judicial review." 122

Conversely, "discourse of disunity" 123 proponents argue that this attempt is "doomed to failure [because it] cannot be united in a noncontroversial way that would grant legitimacy to the political regime and justify the practice of judicial review." 124 Some claim that judicial review is illegitimate, ${ }^{125}$ while others argue that the "irreconcilable tension ... does not need to lead to negative practical conclusions because judicial review can be prudentially justified." 126 As discussed below, neither view is entirely correct.

\section{Judicial Review, Individual Rights, and a Participatory Democracy}

There is nothing inherently problematic with the view that the Constitution protects evolving substantive values; it becomes troublesome when courts have the power to say what those rights are at any given point in time. This is particularly true when the source of those rights is not a reasonable interpretation of the Constitution's text, but an extratextual focus on transcendent and unwritten values. ${ }^{127}$

Under that regime, the Constitution becomes more than a protector of substantive values, but a guarantor of additional, albeit uncertain, future values that, in the judiciary's view, are consistent with contemporary norms. The inherent risk here is that the judiciary no longer acts simply as a check on arbitrary government power, but as a modern-day, nonmajoritarian, and unaccountable rights creator. In other words, courts enforce their interpretation of the Constitution but do not necessarily enforce the textual limits placed on the judiciary itself.

\footnotetext{
120. Id. at 387.

121. Id. at 389 .

122. Id. at 405 .

123. Id. at 386 .

124. Id. at 387.

125. Sultany, supra note 119 , at 387.

126. $I d$.

127. See, e.g., Planned Parenthood of Se. Pa. v. Casey, 505 U.S. 833, 851 (1992) (reaffirming Roe v. Wade based, in part, on the right to "define one's own concept of existence, of meaning, of the universe, and of the mystery of human life"); Lawrence v. Texas, 539 U.S. 558, 562 (2002) (holding that a law banning same-sex sodomy implicated "liberty of the person both in its spatial and in its more transcendent dimensions").
} 
Thus, contemporary liberalism's answer to the dangers of majority rule is to establish oligarchical rule.

One problem with this approach, however, is that it fails to define majority rule in a meaningful way. While majority rule refers primarily to the party in control of one or more branches of government, it fails to appreciate the value of democratic governance in creating substantive, state-specific values. Often, the majority in one state might be the minority in another for legitimate reasons relating to differences in culture, values, or needs. Within states, most citizens, depending on the policy under review, are simultaneously in some majorities and some minorities. A group that succeeds in restricting abortion rights, for example, might also be in the minority in a state that permits euthanasia.

Contemporary liberal theorists do not seem to be arguing that the group restricting abortion rights must be protected from majoritarian tyranny. Instead, they seem to argue that certain specific groups deserve special protections from the courts, regardless of whether the Constitution supports either the asserted right or the judiciary's role in its establishment. ${ }^{128}$ Significantly, the fact that scholars have gone to great lengths to discover unwritten rules and invisible mandates in the Constitution ${ }^{129}$ suggests that they are trying to justify a vision of democracy that is not supported by a reasonable interpretation of the text. Furthermore, because the Court's decisions often apply to citizens of every state, one might ask if they are truly decisions protecting minority rights, or if the Court disregards intrastate autonomy to achieve a result that is pragmatically justified or more to each Justice's liking.

Put differently, making judicial review the centerpiece of the fundamental rights discourse compromises the ability of each state to create a participatory but nontyrannical majority. This undermines procedural and substantive equality because citizens are subjugated to something far worse than majority rule: nonmajoritarian and politically insulated judges. After all, if the Constitution's text cannot reasonably be said to prohibit a particular law, even those that are silly and unwise, it seems odd to say that the Court can nonetheless strike it

128. See, e.g., Keyes, supra note 67 , at 52 (stating that "it is the duty of the judiciary, operating on its independent moral authority, to discover and say what the law is and thereby freely to implement the 'truly democratic' conditions of equality and basic personal liberty on behalf of the people, regardless of the people's own conception of the fair and rational laws most conducive to a flourishing society").

129. See, e.g., Akhil Reed Amar, America's Unwritten Constitution: The Precedents and Principles We Live By (2012); Laurence H. Tribe, The Invisible Constitution 210-11 (2008). 
down. The practical effect is to make everyone a minority under the artificial pretense of equality.

This paradigm represents a misguided form of pragmatism and fails to establish any meaningful constitutional limits on judicial review. The legitimacy of majority rule itself depends on institutional and individual realities such as the procedures governing the passage of laws, and considerations of whether a law complies with federal and state constitutional limits. Certainly, courts are empowered to enforce these limits by relying on both the text of the Constitution as well as reasonable interpretations of its language, but they are not entitled to create what never existed. That the Constitution itself provides a method for changing the Constitution - that is, by amendment-illustrates that the Constitution does not authorize its amendment by judicial fiat.

The words "reasonable interpretation" do not suggest that the courts should be strict textualists, just as they do not imply an originalist perspective. But they do suggest that courts should interpret the words in a manner that is supported by traditional definitions and contemporary uses in various cultural, historical, or legislative contexts. For example, it is one thing to say that, as society has evolved, our understanding of the words "cruel and unusual" 130 has changed. It is quite another, however, to say that the Bill of Rights contains unwritten penumbras justifying the independent creation of a substantive right to privacy under the Fourteenth Amendment's Due Process Clause. ${ }^{131}$ Evolving interpretations of the Eighth Amendment reflect contemporary norms. Manipulation of the Fourteenth Amendment's text is wrong regardless of whether it happened in the eighteenth century or in the twenty-first.

The more important question, however, is where the proper balance lies in a Constitution that is not entirely democratic or undemocratic, but instead "resistant as a whole to any sustained settlement of the kind that either a demagogue or a sovereign authoritative point of

130. U.S. Const. amend. VIII ("Excessive bail shall not be required, nor excessive fines imposed, nor cruel and unusual punishments inflicted.").

131. U.S. Const. amend. XIV, $\S 1$.

All persons born or naturalized in the United States, and subject to the jurisdiction thereof, are citizens of the United States and of the State wherein they reside. No State shall make or enforce any law which shall abridge the privileges or immunities of citizens of the United States; nor shall any State deprive any person of life, liberty, or property, without due process of law; nor deny to any person within its jurisdiction the Id. equal protection of the laws. 
view might try to impose."132 Indeed, the Constitution "rarely finds coherent expression as a whole," 133 and "attempts to construct or reconstruct constitutional meaning ... are frequently arguments over precisely what constitutional ends require."134 As discussed below, the ends, particularly of judicial review, should be to empower citizens within each state to be meaningful actors in governance while independently protecting substantive rights that reasonably flow from the Constitution's text. These ends are consistent with the Constitution's countermajoritarian element, a participatory democracy that eschews normative judicial authority, and its "complex and skillfully contrived blend of liberalism and democracy characterized by tension." 135 This is not to say, of course, that because the Supreme Court is an undemocratic institution its decisions necessarily lead to an undemocratic society. The problems result from decisions that are intended to facilitate democracy, but that require a manipulation of, or disregard for, the Constitution's text. ${ }^{136}$

Contemporary liberalism rejects this view. Instead, it seeks to give the courts extraconstitutional authority-under an expanded interpretation of Marbury v. Madison ${ }^{137}$ and theory of implied rights ${ }^{138}$ - that permits the invalidation of positive law that does not violate any reasonable interpretation of the Constitution's text. As discussed below, this is not remarkable in and of itself. The results, however, tell a problematic story, particularly because courts have accepted the invitation and in many instances declined to exercise institutional restraint. With respect to the Supreme Court, it has discovered penumbras emanating from the Bill of Rights, ${ }^{139}$ invented dubious legal doctrines to imply rights that are not supported by the text, ${ }^{140}$ and

132. Bryan Garsten, Saving Persuasion 208 (2006).

133. George Thomas, Two Cheers for Eighteenth-Century Constitutionalism in the TwentyFirst Century, 67 MD. L. Rev. 222, 226 (2007).

134. Id. at 227.

135. Id. at 225 .

136. See, e.g., Adrian Vermeule, Foreword, System Effects and the Constitution, 123 Harv. L. Rev. 4, 37-38 (2009) ("[I]t is a fallacy of composition to assume that if the Supreme Court is undemocratic, then the constitutional system will be undemocratic overall. An undemocratic Court may be necessary to produce a constitutional order that is democratic overall, because it is needed to offset legislative failures, according to the very democratic benchmark the critics use.").

137. 5 U.S. (1 Cranch) 137 (1803).

138. See, e.g., Randy E. Barnett, The Misconceived Assumption About Constitutional Assumptions, 103 Nw. U. L. Rev. 615, 622 (2009).

139. See, e.g., Griswold v. Connecticut, 381 U.S. 479 (1965).

140. See, e.g., Michael J. Phillips, The Slow Return of Economic Substantive Due Process, 49 Syracuse L. Rev. 917, 957 (1999) ("[It] is wrong when [the Court] use[s] judicially-concocted doctrines like substantive due process to invalidate democratically-created laws.”). 
invoked stare decisis in an inconsistent manner. ${ }^{141}$ To be clear, even the invention of doctrine would not be problematic if it were designed to enhance political equality, but not as it has been used-to concentrate federal judicial power and expand the reach of federal regulatory authority, two unelected monoliths. This may be well-intentioned, but it is antidemocratic and unconstitutional.

\section{The Supreme Court's Liberty Jurisprudence Leads to Procedural and Substantive Inequality}

Many of the Court's "constitutional reconstructions depart significantly from our eighteenth-century Constitution ... [to] the near erasure of the Ninth Amendment, [and] in how we elect presidents." 142 These reconstructions have included reinterpretations of the Constitution's text and have made the Court a primary "moral arbiter[ ] . . and the guarantor[] of social, as well as individual, justice" 143 for all. As a result, procedural equality has been compromised, as citizens are less able to "participate equally in . . . defining their own individual basic personal liberties." 144 It has also created a system where "principles of human liberty" 145 do not embrace "concepts of democracy." 146

While this can be attributed in part to contemporary liberalism's focus on countermajoritarian precepts, ${ }^{147}$ it has more to do with "the political stakes of the power of judicial review granted to life-tenured federal judges." 148 It involves a "debate ... about 'the most extraordinarily powerful court of law the world has ever known." 149

But this has not led to calls for more "active and constant participation ... in the collective power of the political community," ${ }^{150}$ or a

141. See, e.g., David L. Berland, Note, Stopping the Pendulum: Why Stare Decisis Should Constrain the Court from Further Modification of the Search Incident to Arrest Exception, 2011 U. ILL. L. Rev. 695, 700.

142. Thomas, supra note 133, at 226-27.

143. Evelyn Keyes, Two Conceptions of Judicial Integrity: Traditional and Perfectionist Approaches to Issues of Morality and Social Justice, 22 Notre Dame J.L. Ethics \& Pub. Pol'y 233, 253-54 (2008); see also Keyes, supra note 67, at 58.

144. Keyes, supra note 67 , at 58.

145. Breyer, supra note 43 , at 245.

146. $I d$.

147. Nimer Sultany, supra note 119 , at 374.

148. Id. at 383 .

149. Id. (quoting Alexander M. Bickel, The Least Dangerous Branch: The Supreme Court at the Bar of Politics 1 (2d ed. 1986)).

150. Carla D. Pratt, Commentary, Taking Diversity Seriously: Affirmative Action and the Democratic Role of Law Schools: A Response to Professor Brown, 43 Hous. L. Rev. 55, 71 (2006). 
focus on what Justice Breyer calls "active liberty."151 As one scholar argues, "[E]ven if everyone agrees that representative political institutions suffer from ailments . . . such agreement should not lead to excluding citizens from participation and handing decision making to a small group of judges to decide what the ailments are."152 Participatory democracy is not just about procedural equality; it is a substantive value that the Constitution protects, but that contemporary liberalism-and the Court's current majority-reject.

To be sure, the claim that the Constitution protects substantive values and natural rights that "comport with the fundamental nature of human beings" 153 is not controversial. Furthermore, we do not live in a solely procedural democracy that allows for "no constitutional limits on legislation and [accepts] whatever a majority (or other plurality) enacts . . provided the appropriate procedures . . . are followed." 154 Thomas Jefferson, for example, "spoke of natural rights as limiting what any generation acting as popular sovereign can do,"155 and James Madison, while insisting that the "people are the best protectors of their rights," 156 rejected the claim that the "majority is the political standard of right and wrong." 157 In this way, "they tended to draw on a combination of popular sovereignty and natural rights." 158 Additionally, the Bill of Rights unquestionably protects fundamental liberties such as speech, autonomy, and, in certain contexts, privacy. ${ }^{159}$

Thus, judicial review is not ipso facto illegitimate. Courts should play an important role in democratic governance because, as philosopher John Rawls stated, substantive values and "freedoms [are] interpreted by the courts as constitutional limits on legislation." 160 But it is one thing to enforce constitutional limits, and quite another to create new restraints by inference, whether through penumbras or invented legal doctrines. When the Court tries to import specificity to the text's generalized language and discovers additional meanings or implied "rights" that the text cannot reasonably support, it is no longer applying legal rules or canons of construction. It is making a normative

151. Stephen Breyer, Active Liberty: Interpreting Our Democratic Constitution 5 (2005).

152. Sultany, supra note 119 , at 422 .

153. Id. at 232-33.

154. John Rawls, Justice as Fairness: A Restatement 145 (Erin Kelly ed., 2001).

155. Thomas, supra note 133, at 232.

156. Id.

157. Letter from James Madison to James Monroe (Oct. 5, 1786), in Selected Writings of JAMES MAdison 27, 28 (Ralph Ketcham ed., 2006).

158. Thomas, supra note 133, at 232.

159. See, e.g., U.S. Const. amends. I, IV.

160. RAWLS, supra note 154 , at 145. 
judgment about words, such as liberty, that cannot be defined, and a statement about values that people have a right to define for themselves. Facilitating an egalitarian democracy in which citizens can make these choices and have more than a symbolic vote at the ballot box would allow the people to "maintain for themselves, as free and equal citizens, a social compact of ordered liberties."161

So far, the Court's pragmatism, while leading to favorable and sometimes justifiable outcomes for underrepresented groups, has prevented citizens from participating equally and actively in the democratic process. Its decisions have focused too much on equality and liberty as outcome-based goals, rather than process-oriented imperatives. Ironically, the Court's invocation of equality and liberty as a normative justification has, in fact, resulted in less equality, greater concentration of wealth and power, and the compromise of each person's natural right to self-determination.

Put differently, the Court should not use the "coercive power of the law" 162 to make normative judgments about the "fundamental commitments of the political community." 163 To create a truer form of liberty, the Court must facilitate a democratic process whereby the participants are equal and citizens have meaningful "ways in which ... [to] discuss constitutional essentials through formal democratic channels." 164 Of course, while "it is part and parcel of the meaning of democracy to constrain ... the dominant morality of majorities," 165 the Court must also ensure the political equality of individual citizens.

Additionally, while part of the Court's "essentially democratic task" 166 is to constrain legislative bodies, it is for the purpose of ensuring "informed and free participation of citizens" 167 and not to give the judiciary plenary power. Thus, instead of "settling disputes about rights, justice, and democracy," 168 the Court should allow rights to evolve through political decision-making processes "in which all citizens can freely participate in the deliberative process."169 As Rousseau stated, "If . . . the people simply promise[] to obey, it dissolves itself by that act and loses its character as a people; the moment there is a master, there is no longer a sovereign, and forthwith the body

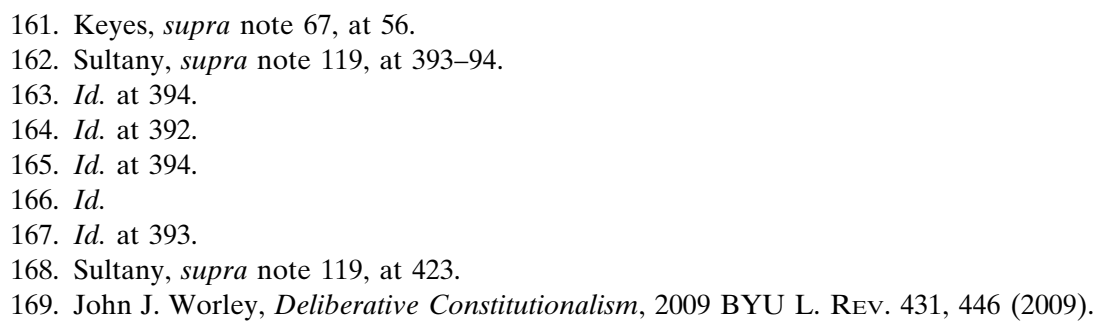


politic is destroyed." 170 Indeed, "to vest authority in any one body to 'speak' for the fundamental law is effectively to make that body sovereign." 171

Of course, contemporary society will never achieve a truly participatory democracy. As one scholar explains, "Whether the pure model of participatory democracy can be translated into larger governmental units is problematical at best." 172 John Stuart Mill also recognizes that "although participation [is] the ideal, it [is] not practical in anything but the smallest town." 173 Furthermore, while "[r]epresentative democracy is a species of participatory democracy to the extent that the representatives ... reflect directly the will of their constituents," 174 even this system is viewed as a "theoretical ideal, unattainable in the modern, highly populated, transnational world." 175

Even in contemporary politics, however, the Court's decisions can significantly optimize participation while also constraining state legislatures from acting outside of their constitutional limits. One scholar explains as follows:

James Wilson insisted that "revolution principles" ought to be taught "as a principle for the constitution of the United States," and during the ratifying conventions he insisted that, "the truth is, that the supreme, absolute and uncontrollable authority, remains with the people." Yet Wilson insisted that this point should legitimize the act of creating a new constitution based on the popular authority of the people, not the states. Indeed, at the end of his speech he insisted that the Declaration of Independence recognized this unalienable right of the people. He quoted the second paragraph of the Declaration, emphasizing that consent legitimizes power because it obligates government to recognize unalienable rights-that is, unalienable individual rights, which are the basis of the right of self-government. ${ }^{176}$

These rights depend on "democratization of the corporate or industrial sector" 177 and "increasing opportunities for full participation in

170. Jean-Jacques Rousseau, The Social Contract (1762), reprinted in The Social Contract; And, the First and Second Discourses 149, 170 (Susan Dunn ed. \& trans., Yale Univ. Press 2002).

171. Thomas, supra note 133 , at 225.

172. Ides, supra note 92 , at 5.

173. $I d$.

174. $I d$.

175. Id. at 6 .

176. George Thomas, supra note 133, at 231-32 (footnotes omitted) (quoting James Wilson, Lectures on Law Delivered in the College of Philadelphia (1790), reprinted in 1 THE Works OF JAMES Wilson 69, 78-79 (Robert Green McCloskey ed., 1967), and James Wilson, Speech to the Pennsylvania Ratifying Convention (Dec. 4, 1787), reprinted in 1 The Founders' ConstituTION 61, 62 (Philip B. Kurland \& Ralph Lerner eds., 1987)).

177. Ides, supra note 92 , at 6. 
decentralized units of government." 178 This gives participants greater personal autonomy and has a "strong potential for dismantling severe economic disparities which may be inconsistent with the political equality necessary for a legitimate participatory democracy." 179 As Professors Stone, Seidman, Sunstein, and Tushnet explain, "Dialogue and discussion among the citizenry were [historically] critical features in the governmental process." 180 Moreover, "[p]olitical participation should be active and frequent and not limited to voting or other similar statements of preference." 181

As former United States Supreme Court Justice Benjamin Cardozo stated, "[T]he juristic philosophy of the common law is at bottom the philosophy of pragmatism." 182 Since "truth is relative, not absolute," 183 and the Constitution accommodates "the particular people it is created for," 184 then they must have a more influential role in a changing society. As one scholar explains, "The challenge therefore is to counteract antidemocratic sentiments and help citizens to develop and cultivate attitudes and values that strengthen democracy."185 After all, as another commentator explains, "citizens unable to hold their leaders accountable collapse into a mood of indifference."186

Ultimately, pragmatism that "protect[s] "higher law [with] . . decisions that reasonably accord with the constitution itself" "187 and enables a participatory democracy will lead to a more equal Constitution that respects diverse understandings of liberty. An examination of the Supreme Court's jurisprudence across the constitutional spectrum, however, shows how separate and unequal the Constitution has become.

\section{Today's Separate but Unequal Constitutions}

In Democracy and Distrust, John Hart Ely stated that "when the Constitution is viewed as a whole, its primary concern is not enshrining substantive rights, but creating a system that encourages represen-

\footnotetext{
178. $I d$.

179. $I d$.

180. Geoffrey R. Stone et al., Constitutional Law 5 (1986).

181. Id.

182. Benjamin N. Cardozo, The Nature of the Judicial Process 102 (1921).

183. $I d$.

184. Thomas, supra note 133, at 236.

185. Okechukwu Oko, The Challenges of Democratic Consolidation in Africa, 43 New Eng. L. REv. 165, 205 (2009).

186. Id. at 204.

187. Sultany, supra note 119, at 392 (quoting John Rawls, Political Liberalism 234 (expanded ed. Columbia Univ. Press 2005) (1993)).
} 
tative democracy."188 The Court's jurisprudence, for the most part, has undermined equality and liberty in the political and democratic processes. While the cases below are merely a sample, they are representative of a jurisprudence, within and across the individual rights' amendments, that devalues equal participation.

\section{A. The Goldman Sachs Constitution}

In Citizens United v. Federal Election Commission, ${ }^{189}$ the Court missed an opportunity to increase citizen participation in the electoral process.

\section{The Decision}

The Court struck down $\S 441(\mathrm{~b})$ of the Bipartisan Campaign Reform Act of 2002 (BCRA), which prohibited corporations and unions from using general treasury funds that "expressly advocate[ed] the election or defeat of a candidate ... and [were] publicly distributed ... within [thirty] days of a primary election." 190 The limitations on corporate and union contributions, which applied to direct or individual expenditures (electioneering communications), were challenged on the ground that they violated the First Amendment. ${ }^{191}$

The Court agreed with this argument, holding that the BCRA "necessarily reduce[d] the quantity of expression by restricting the number of issues discussed . . . and the size of the audience reached." 192 As a result, the BCRA "silenc[ed] certain voices . . . [at] various points in the speech process" that "the government deem[ed] to be suspect," compromising "an essential mechanism of democracy." 193 As one scholar explains, the Court used highly critical language, holding that the restriction is a "ban on speech" 194 which infringed "[t]he right of citizens to inquire, to hear, to speak, and to use information to reach

188. Evan Barret Smith, Representation Reinforcement Revisited: Citizens United and Political Process Theory, 38 VT. L. REv. 445, 447-48 (2013).

189. 558 U.S. 310 (2010).

190. Id. at 320-21; see also 2 U.S.C. §§ 434(f)(3)(A), 441b (2008); 11 C.F.R. § 100.29(a)(2) (2008). The statute also prohibited expenditures within sixty days of a general election. 2 U.S.C. $\S 434(\mathrm{f})(3)(\mathrm{A})$.

191. Citizens United, 558 U.S. at 339.

192. Id. at 339 (quoting Buckley v. Valeo, 424 U.S. 1, 19 (1975) (per curiam)) (internal quotation marks omitted).

193. $I d$.

194. Paul Weitzel, Protecting Citizens from the Heart: How Citizens United Strikes Down Political Speech Restrictions on Churches and Charities, 16 Tex. Rev. L. \& Pol. 155, 163 (2011) (quoting Citizens United, 558 U.S. at 337); see also Amy J. Sepinwall, Citizens United and the Ineluctable Question of Corporate Citizenship, 44 Conn. L. Rev. 575, 581 (2012). 
consensus," and this right "is a precondition to enlightened selfgovernment." 195

While purporting to enhance democracy, the Court's decision did the opposite because it prevented the government from increasing equality in the political process. While the Court acknowledged that preventing corruption in the political process was a compelling government interest, it applied that principle to "quid pro quo corruption" 196 rather than a broader, more systemic corruption. This unduly narrow approach led to a superficial and unrealistic assessment of the pervasive inequalities in national elections. ${ }^{197}$

Justice Stevens vigorously dissented, recognizing that "the distinction between corporate and human speakers is significant," 198 and that that the "financial resources, legal structure, and instrumental orientation of corporations raise legitimate concerns about their role in the electoral process." 199 As such, "lawmakers have a compelling constitutional basis, if not also a democratic duty, to take measures designed to guard against the potentially deleterious effects of corporate spending in local and national races." 200

Justice Stevens criticized the Court's ruling, arguing that it "threatens to undermine the integrity of elected institutions across the Nation"201 and "do damage to this institution."202 Even though the Court had previously recognized the "distinction between corporate and individual campaign spending," in Austin v. Michigan State Chamber of Commerce, ${ }^{203}$ it made no attempt to explain why that holding was no longer controlling. ${ }^{204}$ Additionally, although the Court had allowed states to prohibit corporations from using treasury money to make independent expenditures in McConnell v. FEC,,05 it departed from these principles without any plausible explanation.

195. Citizens United, 558 U.S. at 339.

196. Id. at 345 .

197. See James A. Gardner, The Incompatible Treatment of Majorities in Election Law and Deliberative Democracy, 12 Election L.J. 468, 477 (2013) ("Because most public political speech in the United States is generated privately and disseminated with privately held resources, the institution of campaign speech is built on, and inevitably reproduces, underlying inequalities in the distribution of resources, biasing it in favor of the rich.").

198. Citizens United, 538 U.S. at 394 (Stevens, J., concurring in part, dissenting in part).

199. Id.

200. $I d$.

201. Id. at 396.

202. $I d$.

203. 494 U.S. 652 (1990).

204. Citizens United, 588 U.S. at 395 (citing Austin, 494 U.S. 652).

205. 540 U.S. 93 (2003), overruled by Citizens United, 588 U.S. 310. 
The Court's central argument for why stare decisis ought to be trumped is that it does not like Austin. . . .

... The Court proclaims that "Austin is undermined by experience since its announcement." This is a curious claim to make in a case that lacks a developed record. The majority has no empirical evidence with which to substantiate the claim; we just have its ipse dixit that the real world has not been kind to Austin. Nor does the majority bother to specify in what sense Austin has been "undermined." Instead it treats the reader to a string of non sequiturs: "Our Nation's speech dynamic is changing[;]" "[s]peakers have become adept at presenting citizens with sound bites, talking points, and scripted messages[;]" "[c]orporations . . . do not have monolithic views[.]" How any of these ruminations weakens the force of stare decisis escapes my comprehension. ${ }^{206}$

In fact, Justice Stevens went so far as to say that the Court's rejection of precedent "comes down to nothing more than its disagreement with their results," 207 and is an "amalgamation of resuscitated dissents from those cases." 208 Indeed, the "only relevant thing that has changed since Austin and McConnell is the composition of this Court," 209 which caused Justice Stevens to remind the Court of the importance of adhering to rules that it has "developed ... for its own governance." 210

\section{The Impact on Democracy}

Citizens United damaged procedural and substantive equality in the political process. Justice Kennedy's majority opinion was based, in part, on a fundamental misconception about the dangers of money as a proxy for access: "[A] substantial and legitimate reason, if not the only reason, to cast a vote for, or to make a contribution to, one candidate over another is that the candidate will respond by producing those political outcomes the supporter favors. Democracy is premised on responsiveness." 211 In other words, if representatives give the appearance of being responsive by giving influence or access, this "will not cause the electorate to lose faith in our democracy" because seek-

206. Citizens United, 558 U.S. at 409-10 (Stevens, J., concurring in part, dissenting in part) (second and fourth alterations in original) (citations omitted).

207. Id. at 414 .

208. $I d$.

209. Id.

210. Id. at 395 (alteration in original) (quoting Ashwander v. TVA, 297 U.S. 288, 346 (1936) (Braneis, J., concurring)) (internal quotation marks omitted).

211. Id. at 359 (majority opinion) (quoting McConnell, 540 U.S. at 297) (internal quotation marks omitted). 
ing favor with elected officials is an understood premise and an unavoidable aspect of our democracy. ${ }^{212}$

Justice Kennedy is dead wrong. Citizens become disillusioned with democracy when access and responsiveness are largely influenced by money. This favors the wealthy and reduces voting to little more than a symbolic gesture. That is a recipe for procedural and substantive inequality because it makes politicians accountable to the individuals and groups who fund their campaigns, and to the views they champion. One commentator explains as follows:

An equality rationale undergirds Justice Stevens's reference to power and competitiveness .... Justice Stevens worried about what corruption of the democratic process would lead to because citizens "may lose faith in their capacity, as citizens, to influence public policy. . . . The predictable result is cynicism and disenchantment: an increased perception that large spenders 'call the tune' and a reduced 'willingness of voters to take part in democratic governance."”213

Lawrence Lessig "refers to the Court's factual claim[ ] . . . [that] '[t]he appearance of influence or access ... will not cause the electorate to lose faith in our democracy' as blind Lochnerisms." 214 Indeed, as Michael Waldman states, "[T]he ruling points toward a truly dystopian future, when candidates, campaigns, and parties are drowned out by special interest funding as loud as it is stealthy."215 The late Ronald Dworkin compared "political advertising to beer [ads, arguing that] they threaten the integrity of political debate." 216 The result is a system where access is predicated largely on money.

This is not to say that Citizens United was wrongly decided as a matter of strict constitutional law. The truth is that there is no objectively correct answer. What matters is that Citizens United was wrong for a country that values equality above status. A pragmatic decision would have upheld the statute and "strengthen[ed] the democratic process" by using a "participation-oriented, representation-reinforc-

212. Citizens United, 558 U.S. at 359-60 (majority opinion).

213. Smith, supra note 188, at 454 (alteration in original) (quoting McConnell, 540 U.S. at 144).

214. Id. at 455 (alteration in original) (footnote omitted) (quoting Citizens United, 558 U.S. at $314)$.

215. Id. (quoting Michael Waldman, Supreme Court's Citizens United Decision Will Warp Policymaking, U.S. News \& World ReP. (Sept. 27, 2010, 2:13 PM), http://www.usnews.com/ opinion/articles/2010/09/27/supreme-courts-citizens-united-decision-will-warp-policymaking) (internal quotation marks omitted).

216. Id. at 454 (citing Ronald Dworkin, The Decision That Threatens Democracy, N.Y. Rev. Bоокs, May 13, 2010, at 63, 64, available at http://www.nybooks.com/articles/archives/2010/may/ 13/decision-threatens-democracy/). 
ing approach to judicial review."217 As John Hart Ely explains in Democracy and Distrust, this promotes equal access to, not equal outcomes in, the election and lawmaking process:

[Ely] argues that judges should abandon the search for appropriate values and instead "ensure that the political process-which is where such values are properly identified, weighed, and accommodated-[is] open to those of all viewpoints on something approaching an equal basis. ... Ely's approach attempts to offer a solution to Bickel's "[c]ounter-[m]ajoritarian [d]ifficulty," by arguing that representation-reinforcing judges are not Platonic guardians but are simply acting as referees by "[c]learing the [c]hannels of [p]olitical [c]hange." He likens his approach to an antitrust rather than a traditional regulatory approach-only intervening when necessary to break up a political situation approaching an oligarchy. ${ }^{218}$

As Ely recognized, "money can distort the utilitarian basis for majoritarianism," 219 which is, among other things, to ensure that "minorities have the opportunity for "wheeling and dealing", and are not being "barred from the pluralist's bazaar."220

Thus, while the judiciary should intervene when the "political market . . . is systematically malfunctioning," 221 it should be for the purpose of enhancing democratic liberty and not for the purpose of creating a wealth-driven electoral process. The Court's decision in Citizens United made state legislators less accountable to the voters because citizens lost both political capital at the ballot box and significant value as participants in lawmaking.

\section{B. The Gridlocked Constitution}

In Clinton v. City of New York, ${ }^{222}$ the Court blocked the coordinate branches' efforts to reduce excessive spending and thereby balance the federal budget. 223

217. John Hart Ely, Democracy and Distrust: A Theory of Judicial Review 87 (1980).

218. Smith, supra note 188, at 448 (alterations in original) (quoting Ely, supra note 217, at 71, $74,105)$ (footnotes omitted).

219. Id. at 463 .

220. Id. at 463 (quoting Ely, supra note 217, at 151-52).

221. Alan M. Dershowitz, Tribute, John Hart Ely: Constitutional Scholar (A Skeptic's Perspective on Original Intent as Reinforced by the Writings of John Hart Ely), 40 StAN. L. Rev. 360, 362 (1988).

222. 524 U.S. 417 (1998).

223. Id. at $423,449$. 


\section{The Decision}

In Clinton, both houses of Congress passed, and the President signed, the Line Item Veto Act (Veto Act). ${ }^{224}$ It allowed the President to veto or "cancel in whole" three categories of spending that were previously signed into law and included in duly-passed legislation. ${ }^{225}$ Before vetoing a spending provision, however, the President was required to consider its legislative history and determine that the veto contributed to reducing the federal budget deficit.226 Furthermore, a "lockbox" provision required that monies saved by the veto would not be spent elsewhere. ${ }^{227}$ Congress also had the option to pass a "disapproval bill" that would invalidate the President's veto. ${ }^{228}$

Elevating "form over substance," 229 the Court held that the Veto Act violated article 1, section 7 (the Presentment Clause) of the Constitution. ${ }^{230}$ Justice Kennedy concurred, stating that the line item veto violated the nondelegation doctrine. ${ }^{231}$ The majority acknowledged that "both major political parties ... in the Legislative and Executive Branches have long advocated for the enactment of such procedures" 232 to ensure fiscal accountability. In its view, however, the line item veto allowed the President to create "a different law" 233 than that which was enacted, thus violating the Constitution's "finely wrought" procedures. ${ }^{234}$

In his concurrence, Justice Kennedy argued that the line item veto violated separation of powers principles by "concentrat[ing] power in a single branch." 235 This constituted a "threat to liberty"236 that "tran-

224. Id. at $420-21$.

225. Id. at 436 (quoting 2 U.S.C. § 691(a) (1996)).

226. Id. (citing 2 U.S.C. § 691(b)).

227. Id. at $440-41$.

228. Clinton, 524 U.S. at 436-37 (citing 2 U.S.C. § 691(a)).

229. Eric Stephen Schmitt, Note, There Is No Joy in D.C., The Mighty Court Struck Out: An Analysis of Clinton v. City of New York, The Line Item Veto Act and the Court's Failure To Uphold Constitutionally Legitimate Means to a Viable End, 44 ST. Louis U. L.J. 167, 190 (2000).

230. Clinton, 524 U.S. at 421.

231. Id. at 449, 451-52 (Kennedy, J., concurring). The nondelegation doctrine prohibits Congress from delegating legislative power to another branch of government. Congress may, however, delegate power to another branch or agency to enforce duly enacted legislation or broad policy directives. See, e.g., Mistretta v. U.S., 488 U.S. 361, 372 (1989) ("So long as Congress 'shall lay down by legislative act an intelligible principle to which the person or body authorized to [exercise the delegated authority] is directed to conform, such legislative action is not a forbidden delegation of legislative power.'”) (quoting J. W. Hampton, Jr., \& Co. v. United States, 276 U.S. 394, 409 (1928)).

232. Clinton, 524 U.S. at 447 (majority opinion).

233. Id. at 448 .

234. Id. at 447 (quoting INS v. Chadha, 462 U.S. 919, 951 (1983)).

235. Id. at 450 (Kennedy, J., concurring).

236. $I d$. 
scend[ed] the convenience of the moment."237 In Justice Kennedy's view, liberty is threatened "in a real sense" 238 if one branch is "not subject to traditional constitutional constraints." 239

\section{The Impact on Democracy}

The Court's decision in Clinton prevented democracy from operating more efficiently for the people. Justice Breyer, in a dissent joined by Justices Scalia and O'Connor, argued that the Constitution permits the government to enact legislation in response to contemporary problems. Justice Breyer relied upon the "genius of the Framers' pragmatic vision, which this Court has long recognized in cases that find constitutional room for necessary institutional innovation." 240 One commentator described Justice Breyer's dissent as follows:

The real issue, Breyer felt, was whether Congress could choose to create a contemporary solution (a line item veto) for a problem that did not exist in 1776. Breyer maintained that the Court's previous holdings permitted interdependence and flexible relations between two branches of government in order to secure a "workable government." Breyer quoted Justice Marshall in support of the functional notion that as the times and circumstances change, so may the measures a government adopts to remedy such circumstances. ${ }^{241}$

Justice Breyer also argued that "the [Veto Act] does not violate any specific textual constitutional command, nor does it violate any implicit separation-of-powers principle."242

The Court's decision undermined procedural and substantive equality because it thwarted the government's collective effort to alleviate the effects of excessive spending and partisan politics. The line item veto addressed a "contemporary problem associated with modern-day democracy in America without frustrating or compromising hallowed Separation of Powers goals." 243

Tolerance for government flexibility and innovation is a hallmark of democracy. The [Veto Act] was not inconsistent with the goals of the Separation of Powers doctrine. The President was acting in an executive role and still had no formal function in the legislative process. Some amount of executive discretion should be allowed. In fact, historical evidence shows the Framers may have even believed

237. Id. at 449 .

238. Clinton, 524 U.S. at 451.

239. $I d$.

240. Id. at 472 (Breyer, J., dissenting).

241. Schmitt, supra note 229, at 182 (footnotes omitted) (quoting Clinton, 524 U.S. at 472).

242. Clinton, 524 U.S. at $469-70$.

243. Schmitt, supra note 229, at 189. 
that congressional appropriations were considered permissive and not required.

Part of the genius of the Constitution is its pragmatic vision and "room for necessary institutional innovation." The government must be allowed to delegate authority to those most apt to handle particular problems or policies. ${ }^{244}$

The Court gave little deference to the Veto Act's democratic ends because it was "so concerned with the apparent textual ramifications of the [Veto Act] and its title that it failed to give proper context to a congressional attempt to ... restore the balance of power the Founding Fathers envisioned." 245

Furthermore, as in Citizens United, the Constitution did not compel the Court's holding. As one commentator explains, "[T]here is very little difference between the procedures prescribed by the [Veto Act] and traditional congressional authorization of dollars to be spent on a particular item at the President's discretion." 246 In fact, "the majority would have likely viewed the law differently if it were instead named the 'Decline to Spend Act of 1996," 247 because "Congress has been letting presidents 'decline to spend' for two hundred years and the Court has endorsed these and other bold delegations of power." 248 Apparently, "semantics and a fear of a campaign pledge effectively scared the Court away from allowing a novel experiment," 249 even though "the [Veto Act] expressly comported with the Constitution in an attempt to reform many of the indulgences of modern-day 'logrolling." "250 At its core, Clinton was countermajoritarian in a most undemocratic sense.

\section{The Third Political Branch Constitution}

\section{The Decision}

Democracy took a direct hit during the 2000 Presidential election, when the judiciary had the final word in deciding whether George W. Bush or Al Gore would become the forty-third President of the United States. In Bush v. Gore, ${ }^{251}$ the Court effectively ended the

\footnotetext{
244. Id. at 190 (footnotes omitted) (quoting Clinton, 524 U.S. at 472).

245. Id. at 168-69 (footnote omitted).

246. Id. at 186 .

247. $I d$.

248. $I d$.

249. Schmitt, supra note 229 , at 188 .

250. Id. See generally J. Gregory Sidak \& Thomas A. Smith, Four Faces of the Item Veto: A Reply to Tribe and Kurland, 84 Nw. U. L. Rev. 437 (1990).

251. 531 U.S. 98 (2000) (per curiam).
} 
2000 presidential recount, put to rest the "political question doctrine," and became the third political branch when it held that the Florida Supreme Court's order requiring a statewide recount of "under-votes" violated the Equal Protection Clause. 252 The order "required a manual recount of approximately $42,000 \ldots$ ballots on which automatic machine recounts had failed to detect a vote for President and which had not yet been manually recounted." 253 Officials were required to "count a vote if there was a 'clear indication of the intent of the voter' on the ballot, unless it was 'impossible to determine the elector's choice.'"254

The Court held that this scheme violated the Equal Protection Clause. In its per curiam opinion, the Court held that " $\mathrm{t}]$ he recount mechanisms implemented ... [by] the Florida Supreme Court did not satisfy the minimum requirement for nonarbitrary treatment of voters necessary to secure the fundamental right [to equal protection]." 255 Specifically, the "clear intent standard in manually recounting the under-votes would result in arbitrary and disparate treatment of voters" 256 because it "lacked the specificity that would ensure its equal application." 257 The Court cited, for example, "differences between recounts limited to under-votes and recounts that reexamined all of the ballots cast, and differences between tabulations based on partial recounts versus tabulations based on completed recounts." 258

Furthermore, even if all votes were counted, an official in one county "might count a ballot with an indentation but no separation of the chad from the card, whereas [an official in another county] might not count a similar indentation." 259 Thus, the Court found that "the absence of a uniform standard to be followed in each county for the discernment of voter intent" 260 violated equal protection principles. Consequently, because "it [was] evident that any recount seeking to meet [a] December 12 [deadline] [would] be unconstitutional,"261 the Court held that further remedial attempts were not possible.

252. Id. at $110-11$.

253. Overton, supra note 94 , at 69.

254. Id. (quoting Gore v. Harris, 773 So. 2d 524, 526, 534 n.24 (2000)).

255. Peter M. Shane, Disappearing Democracy: How Bush v. Gore Undermined the Federal Right To Vote for Presidential Electors, 29 Fla. St. U. L. Rev. 535, 550-51 (2001) (first and fourth alteration in original) (quoting Bush v. Gore, 531 U.S. at 105).

256. Overton, supra note 94 , at 69.

257. Id. at 70.

258. Shane, supra note 255 , at 552 (footnote omitted).

259. Overton, supra note 94 , at 70.

260. Shane, supra note 255 , at 551.

261. Bush v. Gore, 531 U.S. at 110. 


\section{The Impact on Democracy}

The Court's decision substituted its own judgment for that of the state officials responsible for bringing the election to a democratic conclusion. It also highlighted the Justices' differing conceptions concerning democracy and citizen participation.

Justices Rehnquist, Scalia, and Thomas supported a "rule-like interpretation, which excluded the [under-votes ... ] consistent with a particular conception of democracy" 262 that belies the fact that "the right to vote is satisfied by the simple opportunity to follow instructions and cast a vote." 263 Justices Kennedy and O'Connor, however, "were concerned that the Court would be exceeding its role if it displaced the [Florida Supreme Court's] interpretation of the state statutory scheme."264 Thus, while Justices Kennedy and O'Connor did not support a rigid application of the rule, their enforcement of the December 12 deadline for selecting state electors "prevent[ed] the state court from exercising any further discretion in counting additional ballots." 265

Of course, rules "promote democratic stability by preventing politics from disintegrating into a confusing and endless disarray of heated disputes, including litigation and violence." 266 Furthermore, "because the border between law and politics is vulnerable ... the discretion afforded through [flexible] standards clouds the boundary by allowing for partisanship, favoritism, arbitrariness, suspicion, distrust, and uncertainty."267

Strict rule application, however, can frustrate democratic processes and devalue active citizen engagement in the political process. As one scholar argues, "[E]nslavement to electoral rules often leads to gross unfairness. . . [because r]igid rules can never anticipate all contingencies, and are often used as political tools of exclusion." 268 Indeed, the "anger, resentment, disillusionment, and frustration that result from the unfairness of rigid rules can promote political alienation, factionalism, political instability, and a decline of commitment to societal mores and laws generally." 269

\footnotetext{
262. Overton, supra note 94 , at 90.

263. $I d$.

264. Id. at 91.

265. Id. at 91-92.

266. Id. at 99.

267. $I d$.

268. Overton, supra note 94, at 100 (footnotes omitted).

269. Id. at 100-01.
} 
For that reason, flexible standards that "provide preset guidelines as to how to facilitate democracy . . . but allow decision[ ]makers to accord the political rights of each citizen individualized importance" 270 help to avoid the unfairness caused by a "mindless application of mechanical rules." 271 Put differently, the "mindless embrace of inflexible electoral rules that dismiss pragmatic concerns about individualized justice" 272 can result in the perception that democracy is not functioning fairly for individual citizens.

The majority's decision made that perception a reality, and underscored the problem of applying fixed legal rules to a democratic problem. In so doing, it emphasized the wrong outcome. Arguably, the decision was designed to "promote democratic stability by preventing politics from disintegrating into .... [an] endless disarray of heated disputes," 273 but came from a federal court that had intervened in a state-run election. And the result, quite possibly, led to some votes not being counted. Like Clinton and Citizens United, Bush v. Gore was not necessarily "wrong" as a matter of constitutional law, but it erred by prioritizing stability over democratic participation.

The point is "not that it is best to apply either rules or standards in every situation." 274 These cases show that, for many constitutional questions that the Court faces, there is no correct answer. That is precisely why citizens, through their representatives, should have the authority to decide these questions.

\section{The Power-Hungry Constitution}

Griswold v. Connecticut ${ }^{275}$ and Roe v. Wade ${ }^{276}$ are but two examples wherein the Court served as a "super legislature" to reach favorable outcomes that had disastrous results for state autonomy and citizen participation. Much more than merely providing judicial review, the Justices have recently embarked on a power grab of epic proportions, enthroning themselves as the arbiters of all that is just, moral, ethical, and American, and not just all that is unconstitutional.

270. Id. at 101 .

271. $I d$.

272. Id. at 102 .

273. Id. at 99.

274. Overton, supra note 94 , at 101.

275. 381 U.S. 479 (1965).

276. 410 U.S. 113 (1973). 


\section{The Decisions}

In Griswold, the Court invalidated a Connecticut statute that prohibited the use of contraception. ${ }^{277}$ Instead of "wait[ing] for the ordinary processes of democratic debate to adjust state policy, the Supreme Court assumed the task of freeing the electorate of Connecticut (and America in general) from a law the dissenting Justices called "silly." 278 The majority's decision, while predicated on the Fourteenth Amendment, was not based on a reasonable interpretation of its text. Instead, the Court discovered "penumbras" in the Bill of Rights, formed by "emanations from those guarantees that help give them life and substance." 279

The majority held that the "[v]arious guarantees [in the Bill of Rights] create zones of privacy," 280 and that these zones prohibit the enactment of laws "which sweep unnecessarily broadly and thereby invade the area of protected freedoms." 281 For example, the Fourth Amendment's guarantee against unreasonable searches and seizures, which would prohibit "the police [from searching] the sacred precincts of marital bedrooms for telltale signs of the use of contraceptives," 282 contains an unwritten privacy right that transferred to other provisions. The Court also held that the privacy zones within the First, Third, Fourth, Fifth, and Ninth Amendments create an affirmative independent right to privacy..$^{283}$

In his dissent, Justice Black recognized that the law, while "uncommonly silly," 284 was not unconstitutional:

277. Griswold, 381 U.S. at 486.

278. Richard G. Wilkins \& John Nielsen, The Question Raised by Lawrence: Marriage, the Supreme Court and a Written Constitution, 83 N.D. L. Rev. 1393, 1396 (2007) (quoting Griswold, 381 U.S. at 527 (Stewart, J., dissenting)).

279. Griswold, 381 U.S. at 484 (majority opinion).

280. $I d$.

281. Id. at 485 (quoting NAACP v. Alabama, 377 U.S. 288, 307 (1964)).

282. Id. at $484-85$.

283. Id. at 484. The Court stated as follows:

The right of association contained in the penumbra of the First Amendment is one, as we have seen. The Third Amendment in its prohibition against the quartering of soldiers "in any house" in time of peace without the consent of the owner is another facet of that privacy. The Fourth Amendment explicitly affirms the "right of the people to be secure in their persons, houses, papers, and effects, against unreasonable searches and seizures." The Fifth Amendment in its Self-Incrimination Clause enables the citizen to create a zone of privacy which government may not force him to surrender to his detriment. The Ninth Amendment provides: "The enumeration in the Constitution, of certain rights, shall not be construed to deny or disparage others retained by the people."

Id.

284. Id. at 527 (Stewart, J., dissenting). 
I feel constrained to add that the law is every bit as offensive to me as it is my Brethren of the majority ... who, reciting reasons why it is offensive to them, hold it unconstitutional. There is no single one of the graphic and eloquent strictures and criticisms fired at the policy of this Connecticut law either by the Court's opinion or by those of my concurring Brethren to which I cannot subscribe-except their conclusion that the evil qualities they see in the law make it unconstitutional.

....

The Court talks about a constitutional "right of privacy" as though there is some constitutional provision or provisions forbidding any law ever to be passed which might abridge the "privacy" of individuals. But there is not. ${ }^{285}$

As Justice Black noted, "There are, of course, guarantees in certain specific constitutional provisions which are designed in part to protect privacy at certain times and places with respect to certain activities."286 These guarantees do not, however, create a separate and fundamental right to privacy. They also risk the arbitrary exercise of judicial power:

The due process argument which [the majority] adopt[s] here is based, as their opinions indicate, on the premise that this Court is vested with power to invalidate all state laws that it considers to be arbitrary, capricious, unreasonable, or oppressive, or on this Court's belief that a particular state law under scrutiny has no "rational or justifying" purpose, or is offensive to a "sense of fairness and justice." If these formulas based on "natural justice," or others which mean the same thing, are to prevail, they require judges to determine what is or is not constitutional on the basis of their own appraisal of what laws are unwise or unnecessary. The power to make such decisions is of course that of a legislative body. Surely it has to be admitted that no provision of the Constitution specifically gives such blanket power to courts to exercise such a supervisory veto over the wisdom and value of legislative policies and to hold unconstitutional those laws which they believe unwise or dangerous. ${ }^{287}$

To be sure, "[o]ne of the most effective ways of diluting or expanding a constitutionally guaranteed right is to substitute for the crucial word or words of a constitutional guarantee another word or words, more or less flexible and more or less restricted in meaning." 288

Justice Black also explained that, by creating an independent right to privacy, the Court used "a broad, abstract and ambiguous concept which can easily be shrunken in meaning but which can also, on the other hand, easily be interpreted as a constitutional ban against many

285. Griswold, 381 U.S. at 507-08 (Black, J., dissenting).

286. $I d$. at 508 .

287. Id. at $511-12$ (footnote omitted).

288. Id. at 509 . 
things."289 Thus, while he "completely subscrib[ed] to the holding of Marbury v. Madison," Justice Black recognized that the Court did not have the authority to "measure constitutionality by our belief that legislation is arbitrary, capricious or unreasonable . . or is offensive to our own notions of 'civilized standards of conduct.'" 290 The Court's power is limited "to strik[ing] down statutes, state or federal, that violate [the] commands of the Federal Constitution."291

In Roe, ${ }^{292}$ the Court invalidated two statutes prohibiting abortion except to save the life of the mother. The majority once again relied on the "penumbras of the Bill of Rights" 293 to hold that "[t]his right of privacy, whether it be founded in the Fourteenth Amendment's concept of personal liberty ... or ... in the Ninth Amendment's reservation of rights to the people, is broad enough to encompass a woman's decision . . . to terminate her pregnancy." 294 The Court made no others attempts to justify its decision, which one scholar called "bad constitutional law, or rather . . . it is not constitutional law and gives almost no sense of an obligation to try to be." 295

\section{The Impact on Democracy}

Griswold and Roe reached results that arguably furthered individual autonomy and liberty. The result, however, was not based on a reasonable construction or expansion of the Constitution's text. Instead, the Court created a new right by engrafting penumbras onto the text of the Constitution, thus filling a logical gap in its analysis and thereby allowing the Court to claim that the decision was based on the text itself. But no amount of legal gymnastics could mask a deeper problem with the Court's decision: it was acting in a normative and extratextual capacity on matters of social policy. One scholar states as follows:

Roe forced America, and the Court, to confront whether the Constitution in fact mandates judicial resolution of social controversies precisely because they are moral, divisive, and difficult. The legal academy that had nurtured privacy analysis and warmly welcomed Griswold now rushed to rewrite and re-explain the Supreme Court's astonishing decision. Thousands of pages in the law reviews were dedicated to sophisticated (and often incomprehensible and contra-

289. $I d$.

290. Id. at 513 (emphasis added).

291. Griswold, 381 U.S. at 513.

292. 410 U.S. 113.

293. Id. at 152.

294. Id. at 153.

295. John Hart Ely, The Wages of Crying Wolf: A Comment on Roe v. Wade, 82 YALE L.J. 920, 947 (1973). 
dictory) justifications for Roe's elimination of democratic debate and decision making at the very moment they were needed most. These obviously post hoc apologetics embarrassed the Court and for many years the Court was hesitant to lengthen the shadows of Griswold. ${ }^{296}$

In both cases, the Court "assert[ed] its undefined and seemingly unlimited power to define for all the fundamental rights it wishes to put beyond the reach of democratic politics at any level of government."297 In so doing, the Court transformed itself into "a super-legislature with the power to invalidate legislation in any manner it wishes."298

Normative judicial review, however, is incompatible with democracy, and undermines the very principles-equality, liberty, and privacy - that its decisions claim to vindicate. Cases such as Griswold and Roe did not actually create "rights" so much as they nationalized policy decisions based on vague principles that are incapable of precise definition, let alone universal application. This has led to a new type of inequality because it gives the Court a greater and unchecked degree of power to invalidate constitutional laws. The views of each citizen and the laws of each state were now subjugated to a Court that transgressed its own limits under Article III and Marbury for the purpose of imposing extra-textual constraints on democracy. The results in Griswold and Roe did not enhance equality. They sacrificed liberty to a new kind of paternalism, whereby the Court's normative decisions became the law for everyone until the Court decides to change it. This is the unwritten rule that emanated from these cases. When the Court's "super legislation" or judicial activism comports with one's own preferences, it is seductive to support the Court's legislative power grab. But one would be well-counseled to remember that the makeup of the Court changes regularly over time, so although one may now bask in the glow of the Court's activism, one may soon find that the Court's activism is diametrically opposed to one's preferences. What then?

\section{E. The Anemic Constitution}

The Court's jurisprudence in other contexts tells a very different story, but with similar results. In the context of Sixth Amendment, the Court has shown extraordinary deference to the states and given

296. Wilkins \& Nielsen, supra note 278, at 1407 (footnotes omitted).

297. Scott Soames, Deferentialism: A Post-Originalist Theory of Legal Interpretation, 82 ForDHAM L. Rev. 597, 612 (2013).

298. Id. 
no substance to the fundamental right to counsel. ${ }^{299}$ In Gideon $v$. Wainwright, ${ }^{300}$ the Court held that the Sixth Amendment, as made applicable to the states through the Fourteenth Amendment, requires that counsel be appointed for indigent defendants. ${ }^{301}$ That right, however, has never been realized. The Court's Sixth Amendment jurisprudence in this regard has been anemic.

\title{
1. The Decisions
}

In Strickland v. Washington, ${ }^{302}$ the Court created a two-pronged standard for governing ineffective assistance of counsel that would prove nearly impossible to satisfy. The Court held that "[f]irst, the defendant must show that counsel's performance was deficient," 303 and second, that "the deficient performance prejudiced the defense." 304

To satisfy the first prong, the defendant is required to show that "counsel's representation fell below an objective standard of reasonableness." 305 The Court explained, however, that "[j]udicial scrutiny of counsel's performance must be highly deferential,"306 stating as follows:

\begin{abstract}
A fair assessment of attorney performance requires that every effort be made to eliminate the distorting effects of hindsight, to reconstruct the circumstances of counsel's challenged conduct, and to evaluate the conduct from counsel's perspective at the time. Because of the difficulties inherent in making the evaluation, a court must indulge a strong presumption that counsel's conduct falls within the wide range of reasonable professional assistance; that is, the defendant must overcome the presumption that, under the circumstances, the challenged action might be considered sound trial strategy. 307
\end{abstract}

Furthermore, counsel is "strongly presumed to have rendered adequate assistance and made all significant decisions in the exercise of reasonable professional judgment." 308

299. See Adam Lamparello, Establishing Guidelines for Attorney Representation of Criminal Defendants at the Sentencing Phase of Capital Trials, 62 ME. L. Rev. 97, 151-53 (2010).

300. 372 U.S. 335 (1963).

301. Id. at $343-44$.

302. 466 U.S. 668 (1984).

303. Id. at 687.

304. $I d$.

305. Id. at 688 .

306. Id. at 689 .

307. Id. (internal quotation marks omitted)

308. Strickland, 466 U.S. at 690. 
The second prong establishes that even if the attorney's performance is "professionally unreasonable," 309 it does not support vacating the conviction if "the error [has] no effect on the judgment."310 In other words, "the Sixth Amendment guarantee of counsel is to ensure that a defendant has the assistance necessary to justify reliance on the outcome of the proceeding" 311 and that "any deficiencies in counsel's performance must be prejudicial to the defense in order to constitute ineffective assistance under the Constitution."312 Thus, even if "particular errors of counsel were unreasonable . . the defendant must show that they actually had an adverse effect on the defense." 313 The Court defined this as a "reasonable probability that, but for counsel's unprofessional errors, the result of the proceeding would have been different." 314

This standard became the vehicle through which horribly inadequate legal representation would be tolerated, and it left indigent defendants with no constitutional remedy for terribly inadequate legal representation. Indeed, the standard "proved virtually impossible for defendants to meet, and instead of raising the bar for effective counsel, the Court created a bar to nearly all assertions of attorney inadequacy." 315 In fact, for sixteen years after Strickland was decided, "the Supreme Court itself failed to find a single instance of constitutionally inadequate representation." 316

Incredibly, "[e]ven in capital cases, where life and death literally hung in the balance, courts often deferred to incomprehensible 'strategic' decisions provided by trial counsel rationalizing their slothful representation." 317

Lawyers have been found to be drunk or drugged, mentally ill, or asleep while representing a defendant. In addition, several recent studies of capital trials reveal that lawyers who represented death row inmates at trial were subsequently disbarred, suspended, or otherwise disciplined at a rate three to forty-six times the average for the relevant states. ... For those attorneys whose clients were exe-

\footnotetext{
309. Id. at 691 .

310. $I d$.

311. Id. at 691-92.

312. Id. at 692 .

313. Id. at 693 .

314. Strickland, 466 U.S. at 694.

315. John H. Blume \& Stacy Neumann, "It's Like Deja Vu All Over Again": Williams v. Taylor, Wiggins v. Smith, Rompilla v. Beard and a (Partial) Return to the Guidelines Approach to the Effective Assistance of Counsel, 34 Ам. J. CRIM. L. 127, 134 (2007).

316. Id. at 134.

317. Id. at 142 .
} 
cuted, the rate of disciplinary sanctions was almost forty times that of the bar as a whole. ${ }^{318}$

This has led to gross inequality in the criminal justice process. In capital cases, for example, defendants have been represented by attorneys who are "not even aware that a separate sentencing proceeding would be held in a capital case" 319 or had "never tried a case to a jury before." 320 Similarly, courts have upheld convictions where one attorney had been "the subject of disciplinary proceedings" and another "virtually incapacitated" 321

Furthermore, the scarce resources allocated to public defenders in some jurisdictions almost ensure that representation there will be inadequate. To begin with, public defenders are "underpaid and overworked" 322 and "ration their services to the most needy clients." 323 Moreover, some indigent defendants are either deprived of counsel entirely or shuffled through the criminal justice system without any meaningful examination of their case. Professor Stephen Bright explains as follows:

An [American Bar Association] report in 2004 reached "the disturbing conclusion that thousands of persons are processed through America's courts every year either with no lawyer at all or with a lawyer who does not have the time, resources, or in some cases the inclination to provide effective representation." A national study in 2009 found that in misdemeanor cases-which far outnumber felonies and which affect millions of people-judges were encouraging defendants to plead guilty without counsel, prosecutors were talking directly with defendants and convincing them to plead guilty without counsel, defendants were discouraged from asking for counsel because of application fees for a public defender as high as $\$ 200$, and defense lawyers usually had too many cases to provide competent representation. ${ }^{324}$

318. Galia Benson-Amram, Protecting the Integrity of the Court: Trial Court Responsibility for Preventing Ineffective Assistance of Counsel in Criminal Cases, 29 N.Y.U. Rev. L. \& Soc. Change 425, 431-33 (2004).

319. Id. at 433 .

320. $I d$. at 434 .

321. Lamparello, supra note 299, at 117 (quoting Bellamy v. Cogdell, 974 F.2d 302, 304 (2d Cir. 1992) (en banc)).

322. Krista M. Anderson, Twelve Years Post Morrison: State Civil Remedies and a Proposed Government Subsidy To Incentivize Claims by Rape Survivors, 36 HARv. J.L. \& Gender 223, 253 (2013).

323. Allison D. Kuhns, Note, If You Cannot Afford an Attorney, Will One Be Appointed for You?: How (Some) States Force Criminal Defendants To Choose Between Posting Bond and Getting a Court-Appointed Attorney, 97 Iowa L. Rev. 1787, 1798 (2012).

324. Stephen B. Bright \& Sia M. Sanneh, Fifty Years of Defiance and Resistance After Gideon v. Wainwright, 122 YAle L.J. 2150, 2162-63 (2013) (footnotes omitted) (quoting Standing Comm. on Legal Aid \& Indigent Defendants, A.B.A., Gideon's Broken Promise: America's Continuing Quest for Equal Justice, at iv (2004), available at http:// 
As Professor Bright explains, "[M]ost state governments have treated the Supreme Court's decision in Gideon not as a bright star pointing the way to justice, but as an unfunded mandate to be resisted." 325 The ABA report quoted by Professor Bright "makes clear that to go from the pretense of representation to the reality of it, there must be a new commitment to counsel and equal justice," 326 which "will occur only when courts begin enforcing the right to counsel, instead of being complicit in its denial." 327

\section{The Impact on Democracy}

The Court's right to counsel jurisprudence makes one question its commitment to liberty and equality. Even in capital cases, the Court has turned a blind eye to shocking examples of incompetent representation, mostly due to a legal standard that few individuals could satisfy. This has made the Sixth Amendment's right to counsel more abstract than real, and has led to procedural and substantive inequality. It is not unfathomable, and is perhaps almost certain, that indigent defendants have been wrongly convicted-and, in some cases, sentenced to death-because of inadequate legal representation. ${ }^{328}$

This approach, and the deference given to states, stands in stark contrast to the Court's Fourteenth Amendment jurisprudence, in which liberty and privacy have been treated as sacrosanct. In the Sixth Amendment context, where liberty and sometimes life are at stake, the Court has allowed states to woefully underfund their public defender programs and effectively ignore the Gideon mandate. The Court's failure to find a single instance of inadequate representation over a sixteen-year period has resulted in the actual deprivation of life and liberty.

Democracy has also suffered. The European Court of Human Rights, for example, has explained "that the European Convention [on Human Rights] is intended to provide practical rights, and . . .

www.americanbar.org/content/dam/aba/administrative/legal_aid_indigent_defendants/ls _sclaid_def_bp_right_to_counsel_in_criminal_proceedings.authcheckdam.pdf).

325. Id. at 2174.

326. $I d$.

327. $I d$.

328. Rebecca Copeland, Getting It Right from the Beginning: A Critical Examination of Current Criminal Defense in Texas and Proposal for a Statewide Public Defender System, 32 ST. Mary's L.J. 493, 502-03 \& n.30 (citing Alan Berlow, Death in Texas: The Capital of Capital Punishment Should Heed Illinois's Example, WAsH. Post, Feb. 13, 2000, at B5 (“[E]ven though Illinois has a public defender system, thirteen people on death row have been found to be innocent since the reinstatement of the death penalty.")). 
access to the courts is a central tenet of a democratic society." 329 In Goldberg v. Kelly, ${ }^{330}$ the Court emphasized that the "general Welfare" and "Blessings of Liberty" are promoted and secured when the poor have "the same opportunities that are available to others to participate meaningfully in the life of the community."331 As one commentator notes, "[T]he seeds of a constitutional right to counsel in civil cases are to be found in Goldberg's emphasis on the values of democratic citizenship and community participation and Gideon's consideration of procedural equality." 332 Unfortunately, however, while the "values of civic participation and procedural equality have a deep pedigree in domestic due process jurisprudence . . . neither Supreme Court nor state court decisions addressing the civil right to counsel have given these values the consideration that they merit." 333

\section{F. The Upside-Down Constitution}

In its Eighth Amendment jurisprudence, the Court has, on the one hand, shown little deference to the States, but on the other, has also given states great latitude in executing criminal defendants with intellectual and psychological impairments. The Founding Fathers created the Constitution to balance the benefits of a centralized government against its risks. Thus, in the pyramid of constitutional power, the people must always maintain a position above the Constitution, which in turn, enjoys a position above the coordinate branches. Of late, the Court has turned this constitutional hierarchy upside down, with the people taking the hind-most. One clear example is the Court's capital punishment jurisprudence, a term used loosely in this context, wherein the Court makes a show of measuring the people's evolving sense of decency by tallying state legislative amendments, but in the end applies its own conception of decency whether it matches the people's conception or not.

\section{The Devolving Definition of Decency}

While "the authors of the Eighth Amendment drafted a categorical prohibition against the infliction of cruel and unusual punishments ...

329. Martha F. Davis, Participation, Equality, and the Civil Right to Counsel: Lessons from Domestic and International Law, 122 Y ALE L.J. 2260, 2278 (2013).

330. 397 U.S. 254 (1970).

331. Martha C. Nussbaum, Foreword, Constitutions and Capabilities: "Perception" Against Lofty Formalism, 121 Harv. L. Rev. 4, 68-69 (2007) (quoting Goldberg, 397 U.S. at 265).

332. Davis, supra note 329, at 2263.

333. Id. at 2281. 
they made no attempt to define the contours of that category." 334 Thus, while the "Eighth Amendment prohibits punishment considered cruel and unusual at the time the Bill of Rights was adopted," it also recognizes "evolving standards of decency that mark the progress of a maturing society." 335 Put differently, "[t]he standard of extreme cruelty is not merely descriptive, but necessarily embodies a moral judgment,"336 the applicability of which "must change as the basic mores of society change." 337

The Court has looked to "objective evidence of how our society views a particular punishment today,"338 to determine whether a punishment is "graduated and proportioned to [the] offense." 339 In its view, "the clearest and most reliable objective evidence of contemporary values is the 'legislation enacted by the country's legislatures, [(including state legislatures)].""340 Legislation tends to "reflect the public attitude toward a given sanction." 341 The Constitution contemplates, however, that "in the [end, the Court's] judgment will be brought to bear on the acceptability of the death penalty under the Eighth Amendment."342 For example, the Court will ask "whether there is reason to disagree with the judgment reached by the citizenry and its legislators." 343 One can see the people, thereby, tumbling down the pyramid.

Importantly, however, the Court has invalidated legislation where no national consensus exists, and where "evolving standards of decency" 344 were certainly subject to reasonable disagreement. In doing so, the Court has established categorical, bright-line rules that have prohibited the states from addressing criminal punishment and sen-

334. Adam Lamparello, Incorporating the Supreme Court's Eighth Amendment Framework into Substantive Due Process Jurisprudence Through the Introduction of a Contingent-Based and Legislatively-Driven Constitutional Theory, 88 NeB. L. Rev. 692, 731 (2010) (alteration in original) (quoting Thompson v. Oklahoma, 487 U.S. 815, 821 (1988) (plurality opinion)).

335. Penry v. Lynaugh, 492 U.S. 302, 330-31 (1989) (quoting Trop v. Dulles, 356 U.S. 86, 101 (1951) (plurality opinion)).

336. Furman v. Georgia, 408 U.S. 238, 382 (1972) (Burger, C. J., dissenting).

337. Graham v. Florida, 560 U.S. 48, 58 (2010) (quoting Kennedy v. Louisiana, 554 U.S. 407, 419 (2008)).

338. Penry, 492 U.S. at 331.

339. Gregg v. Georgia, 428 U.S. 153, 172 (1976) (plurality opinion) (quoting Weems v. United States, 217 U.S. 349, 367 (1910)).

340. Michael J. O'Connor, Note, What Would Darwin Say?: The Mis-Evolution of the Eighth Amendment, 78 Notre Dame L. Rev. 1389, 1403 (2003) (quoting Atkins v. Virginia, 536 U.S. 304, 312 (2002)).

341. Gregg, 428 U.S. at 173.

342. Coker v. Georgia, 433 U.S. 584, 597 (1977) (plurality opinion).

343. Atkins, 536 U.S. at 313.

344. See Ian P. Farrell, Strict Scrutiny Under the Eighth Amendment, 40 FLA. ST. U. L. Rev. 853,857 (2013). 
tencing in nuanced ways. For example, in Roper v. Simmons, ${ }^{345}$ the Court categorically prohibited the execution of juveniles. Writing for the majority, Justice Kennedy held that individuals under the age of eighteen are more immature and irresponsible than adults, "more vulnerable or susceptible to negative influences and outside pressures, including peer pressure," and "have less control, or less experience with control, over their own environment." 346 Traits such as impulsivity and immaturity, which are "more transitory [and] less fixed," 347 led the Court to conclude that crimes committed by juveniles are not within "a narrow category of the most serious crimes" that are "the most deserving of execution." 348

The decision has several flaws. At its core, it was "based on an individual's date of birth and without regard to whether a particular under-eighteen defendant may be death penalty eligible." 349 As commentators note, generalizations and uniformity of treatment "ignore[ ] real differences" 350 and involve "a choice of what factors to leave in and what factors to leave out, and those choices can prove surprisingly complicated."351 Furthermore, Justice Kennedy's "national" consensus was based more on an international consensus, as he noted that "only seven countries other than the United States have executed juvenile offenders since 1990: Iran, Pakistan, Saudi Arabia, Yemen, Nigeria, the Democratic Republic of Congo, and China." 352 Kennedy also found that "[i]n the [fifty-six] years that have passed since the United Kingdom abolished the juvenile death penalty, the weight of authority against it there, and in the international community, has become well established." 353

This reliance may have been motivated by the fact that there was no national consensus on this issue. As Justice Scalia explained in his dissent, only "[eighteen] States-or $47 \%$ of States that permit capital punishment-now have legislation prohibiting the execution of offenders under [eighteen]." ${ }^{354}$ Indeed, "[w]ords have no meaning if the views of less than $50 \%$ of death penalty States can constitute a na-

\footnotetext{
345. 543 U.S. 551 (2005).

346. $I d$. at 569 .

347. Id. at 570 .

348. Id. at 568 (quoting Atkins, 536 U.S. at 319).

349. Ronald Turner, The Juvenile Death Penalty and the Court's Consensus-Plus Eighth Amendment, 17 Geo. Mason U. C.R. L.J. 157, 175 (2006).

350. Frederick Schauer, Profiles, Probabilities, and Stereotypes 260 (2003).

351. Malcolm Gladwell, Troublemakers: What Pit Bulls Can Teach Us About Profiling, New Yorker, Feb. 6, 2006, at 38, 39.

352. Roper, 543 U.S. at 577.

353. Id. at $577-78$.

354. Id. at 609 (Scalia, J., dissenting).
} 
tional consensus." 355 Justice Scalia also took issue with the majority's reliance on the twelve states "that had abandoned the death penalty altogether as part of the consensus against the juvenile death penalty." 356 As he noted, the fact that some "[s]tates favor no executions says something about consensus against the death penalty, but nothing-absolutely nothing — about consensus that offenders under eighteen deserve special immunity from such a penalty." 357 Ultimately, this represented an "attempt by the Court to turn its remarkable minority consensus into a faux majority." 358

Similarly, in Kennedy v. Louisiana, ${ }^{359}$ the Court held that the death penalty for the crime of child rape constituted cruel and unusual punishment. The majority opinion, again written by Justice Kennedy, held that "evidence of a national consensus with respect to the death penalty for child rapists, as with respect to juveniles, mentally retarded offenders, and vicarious felony murderers, shows divided opinion but, on balance, an opinion against it."360 Specifically, only six out of the thirty-seven jurisdictions that authorized the death penalty permitted its imposition for the crime of child rape. ${ }^{361}$

In his dissent, Justice Alito noted that the Court's prior decision in Coker v. Georgia, ${ }^{362}$ which prohibited imposition of the death penalty for the rape of an adult woman, had "stunted legislative consideration of ... whether the death penalty for ... raping a young child is consistent with prevailing standards of decency." 363 Specifically, in Coker, a few Justices had expressed reservations about the death penalty generally, and categorically stated that the death penalty was a disproportionate penalty for rape. ${ }^{364}$ Although Coker did not apply to child rape, it caused hesitation in legislative efforts. As Justice Alito noted, "[W]hen state legislators think that the enactment of a new death penalty law is likely to be futile, inaction cannot reasonably be interpreted as an expression of their understanding of prevailing societal values." 365 Importantly, however, "in just the past few years, despite the

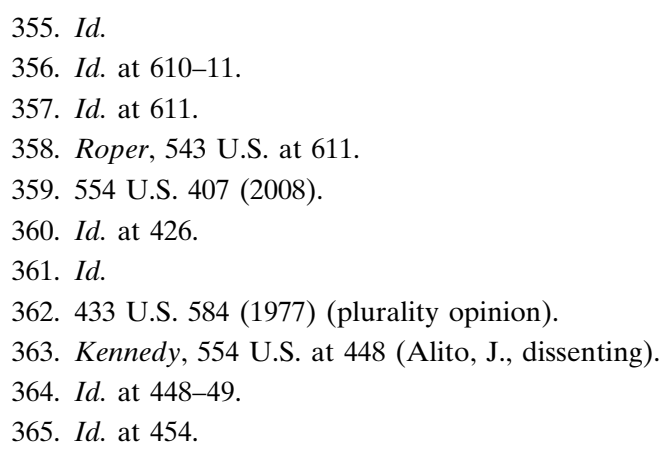


shadow cast by the Coker dicta, five States have enacted targeted capital child-rape laws."366

\section{The Impact on Democracy}

The practical-and lasting-effect of the Court's decision was that it removed a divisive and unsettled policy issue from the political and legislative process. Justice Scalia stated as follows:

If the Eighth Amendment set forth an ordinary rule of law, it would indeed be the role of this Court to say what the law is. But the Court having pronounced that the Eighth Amendment is an everchanging reflection of "the evolving standards of decency" of our society, it makes no sense for the Justices then to prescribe those standards rather than discern them from the practices of our people. On the evolving-standards hypothesis, the only legitimate function of this Court is to identify a moral consensus of the American people. By what conceivable warrant can nine lawyers presume to be the authoritative conscience of the Nation? ${ }^{367}$

In other words, "in a democratic society[,] legislatures, not courts, are constituted to respond to the will and consequently the moral values of the people." 368 If, as the majority argued, our "society is "evolving' toward ever higher 'standards of decency,' these decisions might represent the beginning of a new evolutionary line" 369 that begins and ends with the Court's normative judgments.

The Court has assured us that "the Eighth Amendment is [not] a one-way ratchet that prohibits legislatures from adopting new capital punishment statutes to meet new problems." ${ }^{370}$ But the reality does not match those words. The categorical rules established in Roper and Kennedy, not only prevented legislatures from enacting punishments that, in their view, reflected the depravity of a particular offense, but they effectuated a permanent change to the Eighth Amendment. Thus, the Eighth Amendment's evolution has, in significant part, become a "one-way ratchet" 371 that prevents citizens and states from defining decency and human dignity through principled democratic discourse.

Stated simply, if there is any consensus, it is that the Constitution does not require one. But the Court does-sometimes. To illustrate the bottom line, if any state legislature, in response to a local and se-

366. Id. at 455 .

367. Roper v. Simmons, 543 U.S. 551, 616 (2005) (Scalia, J., dissenting).

368. Id. (quoting Gregg v. Georgia, 428 U.S. 153, 175 (1976) (plurality opinion)).

369. Kennedy, 554 U.S. at 455 (Alito, J., dissenting) (citation omitted).

370. Id. at 469 .

371. Id. 
vere crime problem, were to enact any capital legislation that was not consistent with a majority of the other states, the Court would invalidate that legislation as soon as it was appealed. In fact, the state legislatures, aware of the Court's prior capital punishment decisions, would never waste the state's time and resources to pass that capital legislation in the first place. In that way, the Court is leading and controlling the "evolving standards of decency" and decidedly not letting the States decide for themselves.

\section{Death Is Not Really Different in Democracy}

In its death penalty jurisprudence, however, the Court has been far more hesitant to identify "those offenders who commit 'a narrow category of the most serious crimes' and whose extreme culpability makes them 'the most deserving of execution." 372 Taking an approach similar to its Sixth Amendment jurisprudence, the Court has allowed states to have almost plenary authority over the manner by which the death penalty has been imposed.

In Atkins, the Court held that the Eighth Amendment prohibited the execution of intellectually disabled defendants. In the years following Atkins, however, the Court has allowed states to craft their capital statutes in ways that almost guarantee the execution of intellectually disabled defendants or, at the very least, individuals undeserving of execution. ${ }^{373}$ Some states, for example, place extremely high burdens of proof on defendants seeking to demonstrate intellectual disability. Regardless of the burden of proof, the Court has, until recently, ${ }^{374}$ refused to intervene in cases where individuals later executed showed compelling evidence of cognitive, psychological, and emotional disabilities. In Texas, for example, Marvin Wilson was executed despite scoring 61 on an IQ test, coupled with significant evidence of adaptive and psychological disabilities. ${ }^{375}$ If death is truly

372. Roper, 543 U.S. at 568 (quoting Atkins v. Virginia, 536 U.S. 304, 319 (2002)).

373. See, e.g., Ga. Code Ann. §17-7-131(c)(3), (j) (2013). Georgia is the only state in the country that requires defendants to prove intellectual disability beyond a reasonable doubt, a standard that is nearly impossible to meet, given the imprecise nature of intelligence assessment.

374. Hall v. Florida, 134 S. Ct. 1986 (2014) (holding that Florida statute $\$ 921.137(1)$, which required a defendant to score 70 or below on an IQ test before evidence of adaptive disabilities could be admitted, violated the Eighth Amendment's ban on cruel and unusual punishment).

375. John Rudolf, Marvin Wilson Execution: Texas Puts Man with 61 IQ to Death, HuFFingtON Post (Aug. 7, 2012, 8:53 PM), http://www.huffingtonpost.com/2012/08/07/marvin-wilson-execution-texas_n_1753968.html; see also Mia-Carré B. Long, Of Mice and Men, Fairy Tales, and Legends: A Reactionary Ethical Proposal to Storytelling and the Briseño Factors, 26 Geo. J. Legal Ethics 859 (2013). Texas uses the following Briseño factors when determining intellectual disability: 
different, and the focus is on "individualized consideration," then the procedures for determining death eligibility should also be different.

As one scholar explains, "[C]ourts should be wary when states appear to exercise their sovereignty at the expense of the individual liberty and democratic autonomy that the system of federalism is meant to enhance." 376 In the death penalty context, the Court has been anything but wary of state power, and it has shown that death is different for those with the resources to secure outstanding legal representation.

\section{G. The Laissez-Faire Constitution}

The Court's Commerce Clause jurisprudence has permitted substantial encroachments on state and individual autonomy. ${ }^{377} \mathrm{Al}$ though the Rehnquist Court "increased state autonomy by limiting the federal government's powers through constitutional provisions such as the Commerce Clause and the Tenth Amendment," 378 subsequent decisions have not followed course. ${ }^{379}$

\section{The Decisions}

Commerce Clause jurisprudence can be traced back to the dormant Commerce Clause, which the Court implied from the text of the Con-

1. Did those who knew the person best during the developmental stage-his family, friends, teachers, employers, authorities - think he was mentally retarded at that time, and if so, did he act in accordance with that determination?

2. Has the person formulated plans and carried them through, or is his conduct impulsive?

3. Does his conduct show leadership, or does it show that he is led around by others?

4. Is his conduct in response to external stimuli rational and appropriate, regardless of whether it is socially acceptable?

5. Does he respond coherently, rationally, and on point to oral or written questions, or do his responses wander from subject to subject?

6. Can the person hide facts or lie effectively in his own or others' interests?

7. Putting aside any heinousness or gruesomeness surrounding the capital offense, did the commission of that offense require forethought, planning, and complex execution of purpose?

Id. at 867-68 (quoting Ex parte Briseño, 135 S.W.3d 1, 8-9 (Tex. Crim. App. 2004)).

376. Bradley A. Harsch, Finding a Sound Commerce Clause Doctrine: Time To Evaluate the Structural Necessity of Federal Legislation, 31 Seton Hall L. Rev. 983, 1024 (2001).

377. See Bradford C. Mank, After Gonzalez v. Raich: Is the Endangered Species Act Constitutional Under the Commerce Clause?, 78 U. Colo. L. Rev. 375, 384 (2007) ("From 1937 until 1995, the Supreme Court applied a very lenient rational basis standard for reviewing congressional legislation under the Commerce Clause, and upheld in every case congressional regulation of intrastate activities even if the activities had only indirect impacts on interstate commerce.").

378. Scott A. Keller, How Courts Can Protect State Autonomy from Federal Administrative Encroachment, 82 S. CAL. L. Rev. 45, 47 (2008).

379. See, e.g., Gonzales v. Raich, 545 U.S. 1, 9 (2005). 
stitution, and allows Congress not only to regulate, but to prohibit, state legislation that has an effect on commerce. ${ }^{380}$ The dormant Commerce Clause led to the invalidation of "a myriad of state regulations affecting interstate commerce," 381 including "state licensing requirements, train length restrictions, mudguard requirements, truck length prohibitions, and various produce regulations." 382

Furthermore, in Wickard v. Filburn, ${ }^{383}$ which one commentator called the "the final phase of the New Deal revolution in Commerce Clause jurisprudence," 384 the Court gave Congress the power to regulate activity that occurred wholly within a state's borders. In Wickard, the Court held that Congress "could regulate an individual farmer's production of wheat for home consumption, notwithstanding the fact that this consumption occurred on an entirely intrastate basis and, on its own, undeniably did not have a substantial effect on interstate commerce." 385

The Court held that "the possible aggregate effects on wheat prices and, hence, on interstate commerce of many farmers' home consumption of wheat was sufficient to give rise to federal regulatory authority." 386 Cases that followed affirmed this aggregation theory, and also established a "jurisdictional nexus" 387 requirement that granted "broad federal regulatory authority over things that had previously passed through interstate commerce." 388 Indeed, for over fifty years, until the Court's decision in United States v. Lopez, ${ }^{389}$ it was all but settled that "congressional power under the Commerce Clause, complemented by the authority of the Necessary and Proper Clause . . . extended to all activity that, when aggregated, has a substantial effect on interstate commerce." 390

After Gonzales v. Raich, the Supreme Court appears unwilling or unable to interpret the Constitution to impose meaningful, substantive limits on Congress's enumerated powers. Although the Rehnquist Court flirted with substantive limits on congressional power,

380. Martin H. Redish \& Shane V. Nugent, The Dormant Commerce Clause and the Constitutional Balance of Federalism, 1987 Duke L.J. 569, 570-72.

381. Id. at 574.

382. Id. at $574-75$ (footnotes omitted).

383. 317 U.S. 111 (1942).

384. Gil Seinfeld, The Possibility of Pretext Analysis in Commerce Clause Adjudication, 78 Notre Dame L. Rev. 1251, 1262 (2003).

385. Id.

386. $I d$.

387. Id. at 1264.

388. $I d$.

389. 514 U.S. 549 (1995).

390. United States v. Morrison, 529 U.S. 598, 637 (2000) (Souter, J., dissenting) (citation omitted). 
the specter of such meaningful limits "is now water over the dam." Raich therefore signals that the "political safeguards of federalism" will largely drive the Court's Commerce Clause jurisprudence. According to this view, there are procedural limits on Congress's enumerated powers inherent in congressional representation. Thus, because the states are represented in the national political process, Congress can adequately protect the federal-state balance of power. ${ }^{391}$

When combined with "the Chevron deference [given] to agency interpretations of ambiguous statutory terms" 392 and "underenforcement of the nondelegation doctrine," 393 the Court has allowed Congress to regulate intrastate activity even where the effect on interstate commerce is highly attenuated.

\section{The Impact on Democracy}

The Court's Commerce Clause jurisprudence has upset the balance of federalism between Congress and the states. ${ }^{394}$ One scholar explains that "the system of federalism serves to . . . protect individual liberty and democratic autonomy." 395 It also strives to "maintain the closest possible connection between those who govern and those who are governed; ensure that government remains as responsive as possible to local interests; and preserve the ability of the states to offer diverse solutions to social problems." 396 Thus, "ensuring that federal legislation is preferred to that of the states only when there is a need for it . . . would avoid the unnecessary concentrations of centralized power that are anathema to these important functions." 397

Additionally, "like the express guarantees contained in the Bill of Rights, [federalism] is meant as a guarantor of personal freedom." 398 As such, federalism "was not meant merely to protect the sovereignty

391. Keller, supra note 377 , at 53-54 (footnotes omitted).

392. Id. at 59.

393. Id. at 60.

394. Redish \& Nugent, supra note 380 , at 588-89. The authors summarize the federalism framework as follows:

In one category of situations the states are expressly and absolutely prohibited from enacting certain types of legislation. In the second category, the states must overcome Congress's institutional inertia in order to obtain congressional authorization for the state legislation. In the third category, the states are free to enact legislation; Congress, however, has authority to preempt or overrule such state action by legislation enacted pursuant to one of its enumerated powers.

Id. at 591 .

395. Harsch, supra note 376, at 1010.

396. $I d$.

397. $I d$.

398. $I d$. 
interests of the states," 399 but to "ensure protection of our "fundamental liberties," 400 with states acting as "[the] primary defenders." 401 Thus, the aggregation of power at the national level harms individual liberty, while the states have a responsibility to "protect the rights of their citizens not only by creating and enforcing new rights, but also by simply checking the power of the federal government." 402 As Professor and Judge Guido Calabresi explains, "[F]ederalism is much more important to the liberty and well[-]being of the American people than any other structural feature of our constitutional system." 403 One commentator explains as follows:

The notion of self-governance cannot be anything but a fiction if citizens are so remote from decision-makers that their ability to affect legislation becomes marginal. Thus, when the government exercises power over an individual, the democratic citizen should have some reasonable means of affecting the process by which that power is wielded. 404

In other words, "[t]he more distant the political machinery, the more the average citizen is deprived of the autonomy that is central to democratic ideals." 405

Until the Court's decision in National Federation of Independent Business v. Sebelius, ${ }^{406}$ the Court's Commerce Clause jurisprudence has given Congress wide-ranging power over primarily local activity, and has thereby infringed upon state autonomy and individual liberty. This has led to an implicit type of preemption, whereby broad regulatory policies have constructively deprived the states from offering competing legislation that responds to uniquely local concerns. ${ }^{407}$ In effect, the Court's jurisprudence has aggregated federal power and that has further attenuated the link between lawmaking and citizen participation.

Furthermore, because the Court has invalidated state legislation "even in the absence of a conflicting federal statute," 408 and has used

\footnotetext{
399. $I d$.

400. Id. (quoting Gregory v. Ashcroft, 501 U.S. 452, 458 (1991)).

401. John C. Yoo, The Judicial Safegaurds of Federalism, 70 S. CAL. L. Rev. 1311, 1313 (1997). 402. $I d$.

403. Steven G. Calabresi, “A Government of Limited and Enumerated Powers”: In Defense of United States v. Lopez, 94 Мich. L. Rev. 752, 754 (1995).

404. Harsch, supra note 376, at 1011-12.

405. Id. at 1112.

406. 132 S. Ct. 2566 (2012). In Sebelius, the Court held that the Affordable Health Care Act's individual mandate to purchase health insurance (or face a penalty) was not authorized under the Commerce Clause. Id. at 2593.

407. Catherine M. Sharkey, Against Freewheeling Extratextual Obstacle Preemption: Is Justice Clarence Thomas the Lone Principled Federalist?, 5 N.Y.U. J.L. \& LiberTy 63, 84 (2010).

408. Id. at 80 (quoting Hughes v. Oklahoma, 441 U.S. 322, 326 (1979)).
} 
an aggregate "effects" test ${ }^{409}$ that allows Congress to regulate individual behavior that itself has no impact on interstate commerce, the balance has shifted mightily in favor of the federal government. Thus, in certain areas, federal statutes, not state laws, directly and predominantly govern citizens. And, when the states are shut out of the legislative process, citizens cannot participate meaningfully in the democratic process. Put differently, although every citizen can vote, many citizens do not have a voice in governance.

\section{H. The Live Free or Die Constitution}

The Court's decision in Lochner v. New York, ${ }^{410}$ which invalidated the Bakeshop Act of 1895 (Bakeshop Act), showed the ugly side of substantive due process.

\section{The Decision}

One provision in the Bakeshop Act prohibited employees from working "in a biscuit, bread or cake bakery or confectionary establishment more than sixty hours in any one week, or more than ten hours in any one day." 411 The Bakeshop Act also contained several provisions regulating sanitation, and was largely enacted in response to the sub-standard working conditions to which employees were subject. The New York State legislature unanimously passed the Bakeshop Act, ${ }^{412}$ which came at a time when there were no minimum wage or overtime provisions. ${ }^{413}$

In a 5-4 decision, the Court struck down the hourly and daily work limits. In his dissent, Justice Harlan stated as follows:

[Granting] that there is a liberty of contract which cannot be violated even under the sanction of direct legislative enactment, but ... we may assume, that such liberty of contract is subject to such regulations as the State may reasonably prescribe for the common good and the well-being of society, what are the conditions under which the judiciary may declare such regulations to be in excess of legislative authority and void? Upon this point there is no room for dispute, for, the rule is universal that a legislative enactment, Federal or state, is never to be disregarded or held invalid unless it be, be-

409. Eric R. Claeys, The Living Commerce Clause: Federalism in Progressive Political Theory and the Commerce Clause After Lopez and Morrison, 11 WM. \& Mary Bill RTs. J. 403, 410 (2003).

410. 198 U.S. 45 (1905).

411. Paul Kens, Lochner v. New York: Tradition or Change in Constitutional Law?, 1 N.Y.U. J.L. \& Liberty 404, 407 (2005) (quoting New York Bakeshop Act of 1895, ch. 518, § 1, 1895 N.Y. Laws 305, 305).

412. Id. at $407-08$. The Act passed by a vote of 120-0. Id. at 408 .

413. Id. at 407. 
yond question, plainly and palpably in excess of legislative power. ${ }^{414}$

As one scholar explains, Justice Harlan "plainly thought the majority had ignored a traditional presumption in favor of the workings of democracy." 415 It was based "on a brand of individualism that was far from universally accepted in its time," 416 and, as Justice Oliver Wendell Holmes stated, "an economic theory which a large part of the country does not entertain." 417 While some viewed Lochner as a "recognition of liberty-of-contract doctrine," ${ }_{118}$ the "presumption [it created] in favor of that liberty represented a radical shift or usurpation of power in favor of the federal courts and to the disadvantage of state legislatures." 419

In addition, rather than "reflecting laissez-faire economics," 420 Lochner and its progeny revealed a "concern with government neutrality and opposition to class legislation," 421 which was consistent with the principles of Jacksonian democracy. Jacksonians eschewed "special privilege" or "special legislation" that burdened particular individuals or groups because it created "artificial inequalities of wealth and tended to concentrate political power." 422 They believed that "doling out special privilege created a vicious cycle that threatened both liberty and democracy" 423 because "[a]rtificial inequalities of wealth gave those with the most money the means with which to influence government." 424 Importantly, though, "when Jacksonians took aim at government, they were not thinking of government as a regulator," 425 but rather as "a source of wealth and privilege that put too much power in the hands of too few individuals." 426

414. Lochner, 198 U.S. at 68 (Harlan, J., dissenting).

415. Kens, supra note 411 , at 412.

416. Id. at 411.

417. Id. (quoting Lochner, 198 U.S. at 75 (Holmes, J., dissenting)).

418. Id. at 412-13.

419. Id. at 413 .

420. Id. at 417.

421. Kens, supra note 411, at 417.

422. Id.

423. Id.

424. Id.

425. Id.

426. $I d$. 


\section{The Impact on Democracy}

In many ways, Lochner "remained true to the aspect of Jacksonian democracy that favored government neutrality, but not to its underlying ideals." ${ }^{27}$ At its core, Lochner was hostile to democracy:

It was driven by a fear that the workings of democracy might undermine the economic and social system that had created that wealth. In essence, it turned the ideal of Jacksonian democracy on its head. Implicit in the charge that legislation such as the New York Bakeshop Act was class legislation was the idea that wage earners, farmers, artisans, and laborers represented the forces of political privilege, and that corporations and powerful business interests were the oppressed. ${ }^{428}$

Lochner also ushered in an era of unprecedented judicial power. Thus, when "concentrated corporate power was becoming predominant," workers and reformers ... . turned to the government for help "in the name of individual liberty." 429 The Court accepted the invitation and began issuing rulings that protected individual rights, but at the cost of invalidating legislation that did not violate any express or implied constitutional rights.

Lochner marked the beginning of a more robust and extratextual application of the Fourteenth Amendment's substantive due process doctrine. As Professor Randy Barnett explains, "Lochner is indeed problematic because it violates the original meaning of the Due Process Clause of the Fourteenth Amendment." 430 Indeed, it "distorts the original meaning of 'liberty' in the Due Process Clause by stretching its meaning beyond the matter of deprivation of liberty by imprisonment." ${ }^{431}$ In other words, the "Due Process Clause is aimed mainly at the judicial branch of state governments and enjoins them from sanctioning the violation of otherwise proper laws without following procedures that ensure accurate outcomes." ${ }^{432}$ The Court's interpretation of liberty as a substantive Fourtheenth Amendment guarantee also conveniently gives the Court primary authority over its application to individuals.

The problem is that however the Court defines liberty in a particular case, it is almost always certain to disfavor a particular individual or group, shift power in favor of the federal government, and truncate

427. Kens, supra note 411, at 417.

428. Id. at $417-18$.

429. Id. at 418.

430. Randy E. Barnett, Foreword, What's So Wicked About Lochner?, 1 N.Y.U. J.L. \& Liberty 325,329 (2005).

431. Id. at 332 .

432. Id. at 331 . 
state-wide democratic debate. The Court's definitions have led precisely to this effect. In its Sixth Amendment jurisprudence, for example, the Court has refused to define liberty as protecting egregious instances of incompetent representation. Similarly, in its Eighth Amendment jurisprudence, the Court has allowed states to erect barriers that make it difficult, if not impossible, to demonstrate intellectual disability. Last, the broad deference given to Congress under the Commerce Clause shows little regard for the autonomy or liberty of state governments.

In its Fourteenth Amendment jurisprudence, however, the Court has adopted a Lochner-esque model, wherein liberty has encompassed a broad array of extratextual "rights," stifling democratic discourse. But when the Court relied on First Amendment liberty principles to invalidate campaign finance legislation, it ensured that inequality in the political process would continue. Striking down the line item veto, which was made in the name of liberty and wedded to the Constitution's text, also prohibited the Government from operating more efficiently. These decisions underscore the trappings of a liberty-centered jurisprudence: individuals lose power, representative democracy diminishes, and courts become the arbiters of policy, not simply law.

\section{The "Stare Indecisis" Constitution}

The Court's Fourth Amendment jurisprudence has followed a tortured path as the Court has unnecessarily and unhelpfully engaged in a process of appending exception after exception and doctrine after doctrine in an effort putatively intended to "clarify" the fifty-four words of the Fourth Amendment. That process has resulted in Fourth Amendment interpretations that are unclear, inconsistent, and elevate spurious analogies over constitutional rights. The Court's Fourth Amendment interpretation process has yielded only "stare indecisis." Rather than adding new exceptions and new doctrines, the Court should return to the "reasonableness" standard explicit in the Fourth Amendment.

Reasonableness is not just the Framers' conception; rather, reasonableness is the requirement the people inserted into the Constitution, the contract between the people and the People's government. Any court opinion that uses some artificial exception or inapt analogy to hold constitutional any unreasonable search or seizure is, itself, unconstitutional. In short, unreasonable searches and seizures are unconstitutional whether they fit into some recognized exception or doctrine or not. The Court's flawed Fourth Amendment jurisprudence is not of recent vintage. 


\section{The Decisions}

The Court's Fourth Amendment jurisprudence is rife with artificial exceptions and spurious doctrines that depart from the reasonableness requirement that the people inserted into the Constitution.

The fifty-four words of the Fourth Amendment provide:

The right of the people to be secure in their persons, houses, papers, and effects, against unreasonable searches and seizures, shall not be violated, and no Warrants shall issue, but upon probable cause, supported by Oath or affirmation, and particularly describing the place to be searched, and the persons or things to be seized. ${ }^{433}$

Thus, the constitutional watchword is reasonableness-not wingspan, immediately associated, bright-line, or the like. The clarity of the simple word "reasonableness" notwithstanding, the Court has repeatedly "construed" that simple word in ways that render its meaning unclear, allowing searches and seizures that are undeniably unreasonable. A few examples will suffice to illuminate this point.

In 1967, in Katz v. United States, ${ }^{434}$ the Court was grappling with the advent of electronic means of intercepting landline telephone conversations. ${ }^{435}$ Law enforcement officers installed listening and recording equipment on an outdoor, glass-sided public phone booth; the defendant's side of the conversation was intercepted and used against him in a criminal trial. ${ }^{436}$ The Court held that interception to be an unconstitutional search and seizure. ${ }^{437}$ Arising out of Justice Harlan's concurrence, and moving away from earlier trespass-based Fourth Amendment formulations, ${ }^{438}$ was born the two-pronged subjective and objective reasonable expectation of privacy doctrine. ${ }^{439}$ The Court has largely eschewed trespass formulations ${ }^{440}$ and instead adhered to the reasonable expectation of privacy doctrine since Katz. But the Katz formulation is no improvement at all over the words of the Fourth Amendment itself; in fact, applying the Katz reasonable

\footnotetext{
433. U.S. Const. amend. IV.

434. Katz v. United States, 389 U.S. 347 (1967).

435. Id. at 348 .

436. $I d$. at 348,352 .

437. Id. at $358-59$.

438. See, e.g., Olmstead v. United States, 277 U.S. 438, 466 (1928) (holding that "wire tapping" that does not involve physical intrusion into the protected place is not a Fourth Amendment search).

439. Katz, 389 U.S. at 360-61 (Harlan, J., concurring).

440. There has been at least one recent and notable exception wherein the Court cobbled together a plurality in a GPS tracking case with about half of the plurality Justices applying the $K a t z$ reasonable expectation of privacy formulation and the other half applying a trespass theory. United States v. Jones, 132 S. Ct. 945 (2012). This GPS tracking case is discussed more thoroughly in a later part of this section.
} 
expectation of privacy formula distracts the Court from more straightforward applications of what the Fourth Amendment prohibits- "unreasonable searches and seizures." Simply put, the Katz telephone booth interception was a constitutionally unreasonable search and seizure; the Court need not have invented a new hurdle. The only necessary hurdle is the one that has existed since 1791.

Nowhere is this more evident than in the Court's search incident to arrest jurisprudence. In Chimel $v$. California, ${ }^{441}$ the Court held that law enforcement may conduct warrantless searches of an arrestee's person for the purpose of protecting officer safety and preserving evidence. ${ }^{442}$ In 1973, in United States v. Robinson, the Court evaluated whether officers could search, incident to arrest, the contents of a cigarette pack found in the arrestee's pocket. ${ }^{443}$ Although the question should have been whether the search was constitutionally "unreasonable," the Court devised a new test: whether the item the officers intend to search had been on the arrestee's person at the time of the arrest. ${ }^{444}$ In the years since Robinson, instead of courts focusing on whether the search of items found on the arrestee was reasonable, the courts focused on whether the item had been associated with the person of the arrestee at the time of the arrest. But the "associated with the person of the arrestee" test is not prescribed by the Constitution; rather, the Constitution prescribes the "reasonableness" test. Arising out of the Court's desire to clarify these decisions for officers and courts alike, the Court has only managed to yield more confusion, "stare indecisis," and move further away from what the Constitution requires: reasonableness.

441. 395 U.S. 752 (1969).

442. Id. at 762-63. The Court stated:

When an arrest is made, it is reasonable for the arresting officer to search the person arrested in order to remove any weapons that the latter might seek to use in order to resist arrest or effect his escape. Otherwise, the officer's safety might well be endangered, and the arrest itself frustrated. In addition, it is entirely reasonable for the arresting officer to search for and seize any evidence on the arrestee's person in order to prevent its concealment or destruction.

Id.

443. United States v. Robinson, 414 U.S. 218, 223 (1973).

444. Id. at 235. It is important to note that the Court in Robinson also held that search to be constitutionally reasonable: "It is the fact of the lawful arrest which establishes the authority to search, and we hold that in the case of a lawful custodial arrest a full search of the person is not only an exception to the warrant requirement of the Fourth Amendment, but is also a "reasonable' search under that Amendment." Id. at 235. Nonetheless, subsequent courts applied Robinson not for the constitutional reasonableness holding but for its "found on the person of the arrestee" formulation, thereby moving farther away from the constitutional reasonableness guarantee. 
The "associated with the person" test may have reflected an attempt to determine the reasonableness of law enforcement's conduct, but in practice this test led to an unprincipled expansion of law enforcement's power above and beyond Chimel's original justifications. For example, in 1981, the Court more blatantly elevated expediency over the "reasonableness" guarantee in the Fourth Amendment. In Belton v. New York, ${ }^{445}$ the Court ignored the pure "reasonableness" standard in favor of a bright-line rule that officers could search the interior of a motor vehicle, incident to the arrest of its recent occupant. The Court adopted that bright-line rule rather than adhering to the constitutional reasonableness standard under the theory that officers would find a bright-line rule easier to apply. ${ }^{446}$ But that is the very essence of elevating expedience over constitutional guarantees.

Furthermore, for many years after the Belton bright-line rule was created, lower courts spent much of their time determining whether a search was valid as incident to its occupant's arrest, or whether the arrestee had been a "recent occupant," rather than determining whether the search of the vehicle was reasonable, as the Constitution requires. This was a misdirection of the highest order, diverting officers from their real quest-enforcing law in a manner that is consistent with the Constitution-and diverting courts from their real taskconstruing the constitutionality of those law enforcement actions. What the Court presumably had intended to clarify in order to make both tasks easier, only yielded confusion, indecision, and unconstitutional searches and seizures-"stare indecisis."

In United States $v$. Jones, ${ }^{447}$ the Court continued to wrestle with searches and seizures using technological advancements spawned in the digital era-specifically, warrantless GPS tracking of a suspect vehicle. Again, rather than merely divining whether the GPS tracking "search" was constitutionally "reasonable," the Court straddled two doctrines: the Katz reasonable expectation of privacy, 448 and tres-

445. 453 U.S. 454 (1981) (holding that the search incident to arrest exception extended to motor vehicles when a "recent occupant" had been arrested), abrogated by Davis v. United States, 131 S. Ct. 2419 (2011).

446. As Justice Brennan rued in dissent, "The Court today turns its back on the product of that analysis, formulating an arbitrary 'bright-line' rule applicable to 'recent' occupants of automobiles that fails to reflect Chimel's underlying policy justifications." Id. at 463 (Brennan, J., dissenting) (referring to Chimel v. California, 395 U.S. 752, 762-63 (1969), in which the Court identified the twin rationales for the warrantless search incident to arrest doctrine: (1) officer safety; and (2) safeguarding evidence from destruction or loss).

447. 132 S. Ct. 945 (2012).

448. Id. at $950-52$ (plurality opinion) (elucidating the trespass theory in which Justice Scalia is joined by three Justices). 
pass. ${ }^{449}$ That straddling is not compelled by the Constitution, nor does it help the Court ensure that only "reasonable" searches are permitted.

\section{The Impact on Democracy}

Imagine how many searches have been conducted since Katz was decided in 1967, in which the court found no reasonable expectation of privacy, ending the inquiry there with no additional determination of whether the search was nonetheless constitutionally unreasonable.

Imagine how many searches of items in arrestees' pockets were conducted following the Robinson search incident to arrest doctrine, and imagine how many of those were, in fact, constitutionally unreasonable searches. For example, many would argue that essentially every warrantless search of the memory of an arrestee's cell phone was constitutionally unreasonable, but almost no court has bothered with that question, because the expedience of the Robinson doctrine was so close at hand.

Imagine how many arrestees' vehicles were searched without a warrant in the twenty-eight years between 1981's Belton and 2009's Arizona v. Gant, 450 not because they were deemed constitutionally "reasonable," but because they fit, often quite poorly, ${ }^{451}$ the expedient Belton bright-line rule.

Finally, imagine the uncertainty flowing from the Court's fractured decision in Jones, leaving us all to wonder whether we have returned to the Olmstead trespass formulation, will henceforth apply the Katz reasonable expectation of privacy formulation, or can simply return to

449. Justices Sotomayor and Alito concurred separately and in favor of the reasonable expectation of privacy theory. Id. at 954-57 (Sotomayor, J., concurring); see also id. at 957-64 (Alito, J., concurring). Indeed, Justice Sotomayor signed opinions in favor of both the trespass and reasonable expectation of privacy formulations. Id. at 954 (Sotomayor, J., concurring).

450. 556 U.S. 332 (2009) (effectively reviving the reasonable expectation of privacy doctrine and overturning the Belton bright-line rule for warrantless motor vehicle searches incident to arrest).

451. Belton vehicle searches incident to arrest were deemed constitutional even if the arrestee was in handcuffs, in the locked squad car, and on the way to the stationhouse, all of which could easily be seen as constitutionally unreasonable. See, e.g., United States v. Wesley, 293 F.3d 541 (D.C. Cir. 2002) (upholding the search pursuant to Belton's bright-line rule where the arrestee had been removed from the automobile and was in handcuffs and secured when the warrantless search of the vehicle incident to arrest was conducted). That court read Belton

as creating a bright-line rule that, incident to and contemporaneous with a valid custodial arrest of the occupant of a vehicle, the police may search the passenger compartment of the vehicle without regard to whether the occupant was removed and secured at the time of the search. This reading is in accord with that of every other circuit that has considered the question.

Id. at 549 . 
the Constitution's "reasonableness" guarantee. Contrary to some theories, reasonableness, while a flexible and malleable concept, is not difficult to apply. The Court need not replace constitutional "reasonableness," a concept officers apply routinely throughout every workday, with newer doctrines that simply increase the distance between the people and their constitutional rights. Whenever the Court's decisions yield more "stare indecisis," they create greater uncertainty about whether the people's right to be free from "unreasonable searches and seizures" will be protected against the arbitrary exercise of law enforcement authority. In cases such as Belton, where the answer to that questions was no, the Fourth Amendment was separated from its original purpose, and the Constitution became more unequal for millions of unsuspecting motorists.

\section{J. The Larcenous Constitution}

In Kelo v. City of New London, ${ }^{452}$ the Court broadly interpreted the Fifth Amendment to give local governments unprecedented power to take private property-in essence, condoning larceny.

\section{The Decision}

In Kelo, a local government seized private property as part of a larger redevelopment plan. ${ }^{453}$ The plan included "a waterfront conference hotel anchoring a cluster of restaurants and shops," 454 as well as "a marina, new homes, a museum, and office space." 455 City officials claimed that the plan "would create jobs, generate tax revenue, make the city aesthetically more appealing, and create recreational opportunities." 456

Several local landowners objected to the taking, however, claiming that it was not for "public use." 457 Indeed, the Court acknowledged that the City was "not planning to open all of the condemned land for the general public's use, either through public ownership or transfer of the property to private entities operating public accommodations." 458 Nonetheless, the Court rejected a narrow reading of "public use" and held that the taking was permissible under the Fifth Amendment. ${ }^{459}$

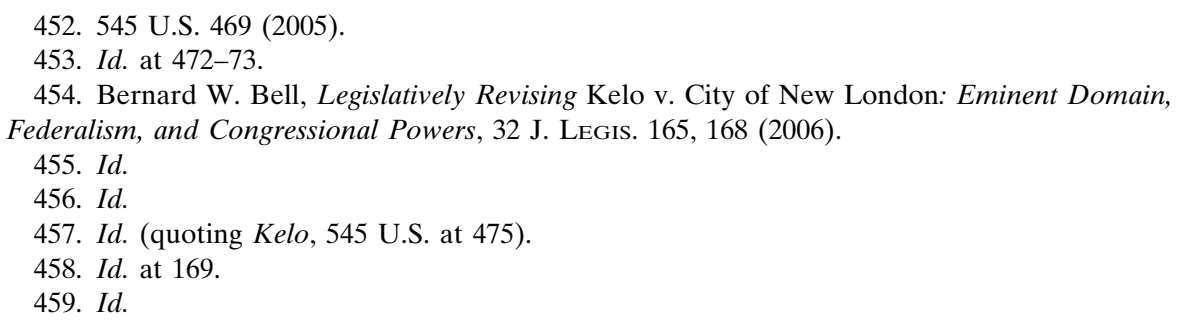


Specifically, the redevelopment plan served an overarching "public purpose," 460 which "has traditionally been defined 'broadly' and reflects the Court's 'longstanding policy of deference to legislative judgments' with respect to such matters." 461 In its view, "[p]romoting economic development [was] a traditional and long accepted function of government," 462 even if part of the development would neither benefit nor be open to the public. The majority explained that it "wisely eschewed rigid formulas and intrusive scrutiny in favor of affording legislatures broad latitude in determining what public needs justify the use of the takings power." 463

In her dissent, Justice O'Connor argued that the Court's decision departed from a "long-held, basic limitation on government power." 464 The city's redevelopment plan did not fall within any of the three well-settled categories defining public use: (1) to transfer "private property to public ownership—such as for a road, a hospital, or a military base;" (2) to transfer private property "to [other] private parties, often common carriers, who make the property available for the public's use-such as with a railroad, a public utility, or a stadium;" and (3) to "serve a public purpose . . . even if the property is destined for subsequent private use." 465 In Justice O'Connor's view, the taking did not fall within any of those categories, and blurred the distinction between public and private uses:

Under the banner of economic development, all private property is now vulnerable to being taken and transferred to another private owner, so long as it might be upgraded-i.e., given to an owner who will use it in a way that the legislature deems more beneficial to the public - in the process. To reason, as the Court does, that the incidental public benefits resulting from the subsequent ordinary use of private property render economic development takings "for public use" is to wash out any distinction between private and public use of property - and thereby effectively to delete the words "for public use" from the Takings Clause of the Fifth Amendment. ${ }^{466}$

Thus, "[a]ny property may now be taken for the benefit of another private party," 467 and the "beneficiaries are likely to be those citizens with disproportionate influence and power in the political process, in-

460. Bell, supra note 454, at 169 (quoting Kelo, 545 U.S. at 480).

461. Id. (quoting Kelo, 545 U.S. at 480).

462. Kelo, 545 U.S. at 484.

463. Id. at 483 .

464. Id. at 494 (O'Connor, J., dissenting).

465. Id. at 497-98.

466. Id. at 494 .

467. Id. at 505 . 
cluding large corporations and development firms."468 Justice Thomas echoed these concerns in his dissent, stating that "[s]omething has gone seriously awry with this Court's interpretation of the Constitution." 469

\section{The Impact on Democracy}

The Court's decision embraced a view of democracy that is hostile to individual rights and liberty. It also highlighted the two drastically different viewpoints concerning the nature and function of a democracy and the role that individuals should have as participants. One commentator describes the majority as subscribing to the Blackstone and Hobbesian view, which "sees the government as primary and individuals as secondary." 470 Proponents of this approach believe that "rights are created by the society for certain prudential reasons, and when society's 'diverse and always evolving needs' require that the citizen relinquish those rights, the courts should not stand in the way." 471 The Lockean view, on the other hand, "sees government as a tool for protecting the rights of individuals against the wrongs of others, and sees the overriding goal of constitutionalism as preventing government from being perverted into a tool for violating those rights." 472

By embracing the Hobbesian view, the Court embraced a view of individual liberty that was far removed from other constitutional contexts and applied a pragmatism that dismissed the importance of a participatory democracy. In many ways, Kelo demonstrates just how distorted our constitutional jurisprudence has become. There is no internal consistency underlying the Court's decisions, and certainly no clear commitment to the Constitution's substantive values of liberty, equality, and democratic governance. The principle that does emerge from these and other decisions is that the Court places government, particularly at the federal level, atop the constitutional pyramid. Individuals have a right to privacy that encompasses abortion, but indigent criminal defendants do not have a meaningful right to counsel; citizens have little more than a symbolic vote at the ballot box; and property owners are subject to eminent domain powers that benefit other private economic interests. This is neither a society of self-governance,

\footnotetext{
468. Kelo, 545 U.S. at 505.

469. Id. at 518 (Thomas, J., dissenting).

470. Timothy Sandefur, Mine and Thine Distinct: What Kelo Says About Our Path, 10 CHAP.

L. Rev. 1, 48 (2006).

471. Id.

472. $I d$.
} 
nor is it a system governed by law. It is rule by the elite, dominated by power and wealth. The result is not simply disillusionment with the political process. It is the loss of liberty and equality in a fundamental sense, and the culprit is the Court's presumably well-intentioned but misguided pragmatism.

Ultimately, there is no perfect solution to these problems. But that is the point. If states are the laboratories of democracy, then they must be permitted to experiment with policies that address the unique needs of their residents. While states must, of course, operate within constitutional constraints, including reasonable extensions of the text, they are also entitled to the benefits of the Constitution's vision for de-centralized governance. This means giving states and their citizens the power to the define equality, liberty, and democracy in different ways, and the authority to enact regulations that equalize access to the political process.

\section{Reasonably Construing the Constitution's Text, Protecting Individual Rights, and Preserving DEMOCRACY}

The above discussion does not mean that the Court should narrowly construe the Constitution's text, apply a strictly originalist perspective, or ignore the evolution of our society. But it does suggest that a primary consideration in constitutional cases should be "whether the opportunity to participate ... in the political processes . . . has been unduly constricted." 473

A pragmatic approach that eschews unsupported interpretations of the text and normative authority, in favor of facilitating egalitarian democratic processes, can ensure that individual rights and procedural equality are protected against arbitrary deprivation. Below is an example in which the Court has interpreted the Constitution's text reasonably, and in so doing, enhanced both of these values.

\section{A. Pragmatism and Individual Rights: United States v. Windsor}

In United States $v$. Windsor, ${ }^{474}$ the Court correctly held that the Defense of Marriage Act (DOMA), which confined the definition of marriage to opposite-sex couples, impermissibly discriminated against homosexuals and therefore violated the Equal Protection Clause. ${ }^{475}$

473. ELy, supra note 217, at 77 (discussing Carolene Products v. United States, 304 U.S. 144 (1938)).

474. 133 S. Ct. 2675 (2013).

475. Id. at 2693 . 
As the Court noted, "moral disapproval of homosexuality" 476 was not a legitimate basis upon which to exclude an entire group of citizens from the substantial federal benefits that opposite sex couples receive.

The Court's landmark decision was an important step forward in the fight for marriage equality. However, Justice Kennedy's decision was tainted with the same type of extratextual rhetoric that drove the Court's earlier substantive due process decisions. For example, Justice Kennedy stated that DOMA was "unconstitutional as a deprivation of the liberty of the person protected by the Fifth Amendment of the Constitution." 477 The opinion also stated that DOMA "imposes a disability" 478 and results in "second tier marriage[s]." 479 Ultimately, while Justice Kennedy invoked the "powerful language of liberty, equality, and dignity," 480 the Court ordered a "limited form of change." 481

The more pragmatic and democratic approach would have been to invalidate DOMA, and same-sex marriage bans generally, based on the text of the Equal Protection Clause. ${ }^{482}$ Some may argue that this is not necessarily consistent with the clause's original meaning, ${ }^{483}$ but it is a reasonable extension of the text-and right-that the Equal Protection Clause seeks to achieve. Equality would have little meaning if it required only the equal administration of laws that in themselves cause inequality. Procedural and substantive equality require much more. With respect to same-sex marriage bans, they require states to provide, at the very least, a rational basis for limiting marriage to heterosexual couples. Thus far, the states have provided no

\footnotetext{
476. $I d$.

477. Id. at 2695.

478. Id. at 2695-96; see also Douglas NeJaime, The View from Below: Public Interest Lawyering, Social Change, and Adjudication, 61 UCLA L. Rev. Discourse 182, 203 (2013); Jerry Elmer, United States v. Windsor: Another Victory for Gay Rights, 62 R.I. B.J., Sept./Oct. 2013, at 13,32 .

479. 133 S. Ct. at 2694.

480. NeJaime, supra note 478, at 203.

481. Id.

482. U.S. Const. amend XIV, § 1.

All persons born or naturalized in the United States, and subject to the jurisdiction thereof, are citizens of the United States and of the State wherein they reside. No State shall make or enforce any law which shall abridge the privileges or immunities of citizens of the United States; nor shall any State deprive any person of life, liberty, or property, without due process of law; nor deny to any person within its jurisdiction the equal protection of the laws.

483. Ryan C. Williams, Originalism and the Other Desegregation Decision, 99 VA. L. Rev. 493, 576-78 (2013) (explaining that a narrow interpretation is not compelled by the original meaning or intent of the Fourteenth Amendment).
} Id. 
such justification, ${ }^{484}$ and the true motive underlying these bansmoral disapproval of same-sex couples-is precisely what the Equal Protection Clause forbids.

But the Court did not send this message in Windsor because its opinion was overrun with powerful rhetoric and generalized platitudes about liberty. While this language certainly reflected hostility toward DOMA itself, it was not grounded in the Constitution's text or on the rights guaranteed therein. As a result, the Court in Windsor "blurred doctrinal categories," 485 and failed to say what the Constitution and Marbury give it the duty to say: these laws have no rational basis whatsoever and offend the textual guarantee of equality. An equalitybased decision would have demonstrated judicial restraint, a commitment to the Constitution's inalienable rights, and given same-sex couples a stronger voice in the democratic process.

\section{B. Intrastate Application of the Eighth Amendment}

The Court's pragmatism must ensure that the constitutional limits it places on state governments and individuals also apply to its decisionmaking process. Otherwise, the Court will continue to be the unchecked final arbiter of a law's constitutionality while simultaneously retaining the power to rewrite or expand that law. That would, in effect, allow the Court to have legislative oversight authority, subject to only those textual restraints that the Court chooses to impose on itself. There is nothing separate or equal about such a system, particularly in a society that values checks and balances.

One way that the Court can balance its countermajoritarian duty with the promotion of egalitarian democratic processes is to adopt an intrastate application of the Eighth Amendment. In other words, instead of issuing decisions that become national policy, the Court should restrain the reach of its decisions to the state within which the law was enacted.

Thus, in assessing the "evolving standards of decency that mark the progress of a maturing society," 486 the Court would search for a local, not national, consensus. It would assess public support for a particular law based on opinion polls within that state, and on the uniquely local needs to which the law responds. In so doing, the "judgment reached

484. See, e.g., Baskin v. Bogan, 766 F.3d 648, 660-61 (7th Cir. 2014) (rejecting the argument that protecting child welfare justifies same-sex marriage bans).

485. Eric Berger, Lawrence's Stealth Constitutionalism and Same-Sex Marriage Litigation, 21

WM. \& MARY Bill RTs. J. 765, 778 (2013).

486. Trop v. Dulles, 356 U.S. 86, 101 (1958). 
by the citizenry and its legislators" 487 would more directly reflect the views of those who actually participated in the law's enactment.

Additionally, in the criminal context, the Court would consider the punishments given for similar crimes in that state, the public support for a particular criminal sanction, and the sentences of juries within that state, to ascertain "the [local] public attitude toward a given sanction." 488 This type of review would recognize that the public attitudes most worthy of consideration are the attitudes of the people within that state-those to whom the law applies, and who are responsible for its creation.

Ultimately, an intrastate paradigm would apply where laws do not plainly or facially violate the Constitution's text. This paradigm would recognize that states have a right to be different, provided that they adhere to the outer limits imposed by the Constitution. Uniformity does not lead to a "better" form of equality, just like it did not make the sentencing process fairer. 489 It does not account for people's diverse perspectives on issues relating to life and liberty, and does not accord sufficient respect for local democratic processes. In fact, it disrespects the substantial differences, values, and perspectives that citizens within each state are constitutionally entitled to have.

This approach would also give a more democratic and constitutionally significant voice to the views of citizens within each state. For example, if Louisiana decides to execute individuals who are convicted of child kidnapping and rape resulting in great bodily harm and mental anguish, and the public attitude supports such a sanction, it should have that right. Likewise, if New York decides to ban all corporate campaign contributions during gubernatorial races, it should be permitted to do so. If Minnesota passes legislation outlawing the manufacture of videos depicting the torture of animals, ${ }^{490}$ it should not face invalidation by the Court.

Letting New York do things one way, while Louisiana and Minnesota do it another, is not a novel idea. But it does not factor into the Court's constitutional jurisprudence, even though it is an ideal method by which to facilitate meaningful citizen participation at the state level and could contribute to a more robust democratic discourse in which

\footnotetext{
487. Atkins v. Virginia, 536 U.S. 304, 313 (2002).

488. Gregg v. Georgia, 428 U.S. 153, 173 (1976) (plurality opinion).

489. See, e.g., Kevin R. Reitz, Sentencing Facts: Travesties of Real-Offense Sentencing, 45 StAN. L. Rev. 523 (1993).

490. See United States v. Stevens, 559 U.S. 460 (2010) (invalidating 18 U.S.C. § 48, which banned "the commercial creation, sale, or possession of certain depictions of animal cruelty," on the ground that it was unconstitutionally overbroad).
} 
laws change from the bottom up and not the top down. If, for example, citizens are unhappy with a particular law, they can collectively advocate for change or petition the state courts for redress. As it stands now, citizens have too little influence, and federal courts have far too much power.

Intrastate judicial review would also ensure that all three branches of government adhere to the limits imposed by the Constitution. In Washington v. Glucksberg, ${ }^{491}$ the Court stated as follows:

By extending constitutional protection to an asserted right or liberty interest, we, to a great extent, place the matter outside the arena of public debate and legislative action. We must therefore "exercise the utmost care whenever we are asked to break new ground in this field," lest the liberty protected by the Due Process Clause be subtly transformed into the policy preferences of the Members of this Court. ${ }^{492}$

This exception, of course, would apply in situations where laws plainly violate the Constitution's text. That is when uniformity is not only desirable, but is required by the Constitution. This rule would ensure that much of what has changed in recent jurisprudence would remain the same. The laws overruled in cases such as Brown v. Board of Education ${ }^{493}$ and Loving v. Virginia ${ }^{494}$ would not suddenly become constitutional. They were never constitutional, and exemplify the arbitrary and injurious exercise of state power. And this is not to say that restrictions on abortion can never be unconstitutional. Perhaps, as one court has held, they constitute gender discrimination ${ }^{495}$ or, as some have argued, violate the equal protection clause. The point is that, before a law is invalidated, there must be a legitimate constitutional basis. In cases such as Roe, there was none.

\section{CONClusion}

The Constitution should not be a political chess match, and outcomes should not depend to such a large degree on the composition of the Court. The text's written and unwritten mandates speak to a single value that should unite jurists of all interpretive persuasions: the people, and not legislatures or courts, own the Constitution's enumer-

491. 521 U.S. 702 (1997).

492. Id. at 720 (citations omitted) (quoting Collins v. Harker Heights, 503 U.S. 115, 125 (1992)).

493. 347 U.S. 483 (1954).

494. 388 U.S. 1 (1967).

495. Baehr v. Lewin, 852 P.2d 44, 59 (Haw. 1993); see also Susan Frelich Appleton, Missing in Action? Searching for Gender Talk in the Same-Sex Marriage Debate, 16 Stan. L. \& Pol'y Rev. 97 (2005). 
ated rights and have a corresponding right to define those that are not enumerated. But those rights have not been fully realized because the Constitution has been applied in a separate and unequal manner.

The wealthy have increased access to the political process, the poor are disproportionately affected by the criminal justice system, and the Court has the final say in many matters that should be left to the democratic discourse. The Constitution does not always guarantee equal outcomes, but it does envision equal access, which is the predicate to an active and evolving form of liberty. The Court should embrace a new form of pragmatism that enhances each citizen's participation in local and national governance, and that eschews overly narrow or impermissibly broad interpretations of the text. If the Constitution cannot guarantee procedural and substantive equality for all, then active liberty and participatory democracy will belong to the few. 
